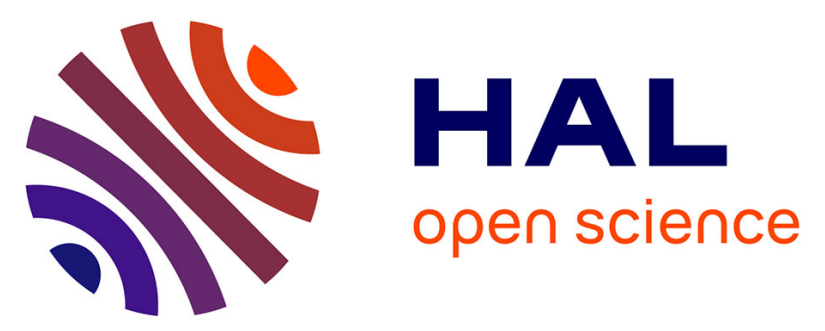

\title{
Overexpression of Spock2 in mice leads to altered lung alveolar development and worsens lesions induced by hyperoxia
}

\author{
Alice Hadchouel, Marie-Laure Franco-Montoya, Sophie Guérin, Marcio Do \\ Cruzeiro, Mickael Lhuillier, Bruno Ribeiro Baptista, Laurent Boyer, Sophie \\ Lanone, Christophe Delacourt
}

\section{To cite this version:}

Alice Hadchouel, Marie-Laure Franco-Montoya, Sophie Guérin, Marcio Do Cruzeiro, Mickael Lhuillier, et al.. Overexpression of Spock2 in mice leads to altered lung alveolar development and worsens lesions induced by hyperoxia: over expression of Spock2 and altered lung development. American Journal of Physiology - Lung Cellular and Molecular Physiology, 2020, 319 (1), pp.L71-L81. 10.1152/ajplung.00191.2019 . inserm-02920089

\section{HAL Id: inserm-02920089 https://www.hal.inserm.fr/inserm-02920089}

Submitted on 24 Aug 2020

HAL is a multi-disciplinary open access archive for the deposit and dissemination of scientific research documents, whether they are published or not. The documents may come from teaching and research institutions in France or abroad, or from public or private research centers.
L'archive ouverte pluridisciplinaire HAL, est destinée au dépôt et à la diffusion de documents scientifiques de niveau recherche, publiés ou non, émanant des établissements d'enseignement et de recherche français ou étrangers, des laboratoires publics ou privés. 


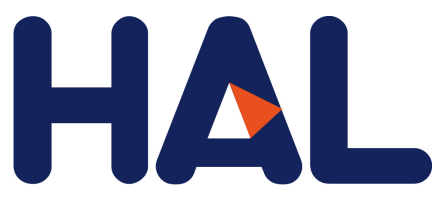

archives-ouvertes

\title{
Overexpression of Spock2 in mice leads to altered lung alveolar development and worsens lesions induced by hyperoxia
}

\author{
Alice Hadchouel, Marie-Laure Franco-Montoya, Sophie Guérin, Marcio Do \\ Cruzeiro, Mickael Lhuillier, Bruno Ribeiro Baptista, Laurent Boyer, Sophie \\ Lanone, Christophe Delacourt
}

\section{To cite this version:}

Alice Hadchouel, Marie-Laure Franco-Montoya, Sophie Guérin, Marcio Do Cruzeiro, Mickael Lhuillier, et al.. Overexpression of Spock2 in mice leads to altered lung alveolar development and worsens lesions induced by hyperoxia: over expression of Spock2 and altered lung development. American Journal of Physiology - Lung Cellular and Molecular Physiology, American Physiological Society, 2020, 319 (1), pp.L71-L81. 10.1152/ajplung.00191.2019 . inserm-02920089

\section{HAL Id: inserm-02920089 https://www.hal.inserm.fr/inserm-02920089}

Submitted on 24 Aug 2020

HAL is a multi-disciplinary open access archive for the deposit and dissemination of scientific research documents, whether they are published or not. The documents may come from teaching and research institutions in France or abroad, or from public or private research centers.
L'archive ouverte pluridisciplinaire HAL, est destinée au dépôt et à la diffusion de documents scientifiques de niveau recherche, publiés ou non, émanant des établissements d'enseignement et de recherche français ou étrangers, des laboratoires publics ou privés. 


\section{Over-expression of $S p o c k 2$ in mice leads to altered lung alveolar development and worsens lesions induced by hyperoxia}

Alice Hadchouel ${ }^{1.2 .3}$, Marie-Laure Franco-Montoya ${ }^{1}$, Sophie Guerin ${ }^{1.2}$, Marcio Do Cruzeiro ${ }^{4}$, Mickaël Lhuillier ${ }^{5}$, Bruno Ribeiro Baptista ${ }^{2}$, Laurent Boyer ${ }^{2}$, Sophie Lanone ${ }^{2}$, Christophe Delacourt $^{1.2 .3}$

${ }^{1}$ AP-HP, Hôpital Universitaire Necker-Enfants Malades, Service de Pneumologie et d'Allergologie Pédiatriques, Paris, 75743 Cedex 15, France

${ }^{2}$ INSERM, U955, Equipe 4, Créteil, 94000, France

${ }^{3}$ Paris University, Paris, France

${ }^{4}$ Homologuous Recombination, Cochin Institute, University Paris Descartes, Paris, France

${ }^{5}$ INSERM, U1151, Institut Necker Enfants Malades, Université de Paris, Paris, France

Corresponding author:

Alice Hadchouel

Service de Pneumologie et Allergologie Pédiatriques

Hôpital Necker-Enfants Malades

149 rue de Sèvres

75015 Paris

Tél : +331444948 47/4955

Fax : +3314438 1740

Mail : alice.hadchouel-duverge@aphp.fr

Running head (60 caractères espaces compris): over expression of Spock2 and altered lung development 


\section{Abstract}

SPOCK2 was previously associated with genetic susceptibility to bronchopulmonary dysplasia in a French population of very preterm neonates. Its expression increases during lung development and is increased after exposure of rat pups to hyperoxia as compared to controls bred in room air.

To further investigate the role of SPOCK2 during lung development, we designed two mouse models, one that uses a specific anti-Spock2 antibody and one that reproduces the hyperoxiainduced Spock2 expression with a transgenic mouse model resulting in a conditional and lungtargeted over-expression of Spock2.

When mice were bred under hyperoxic conditions, treatment with anti-Spock 2 antibodies significantly improved alveolarization. Lung over-expression of Spock2 altered alveolar development in pups bred in room air and worsened hyperoxia-induced lesions. Neither treatment with anti-Spock2 antibody, nor over-expression of Spock2 were associated to abnormal activation of mmp2. These two models did not alter the expression of known players in alveolar development.

This study brings strong arguments for the deleterious role of SPOCK2 on lung alveolar development especially after lung injury, suggesting its role in BPD susceptibility. These effects are not mediated by a deregulation in metalloproteases activity and in expression of factors essential to normal alveolarization. The balance between type 1 and 2 epithelial alveolar cells may be involved.

Keywords: lung development, bronchopulmonary dysplasia, Spock2, transgenic model 


\section{INTRODUCTION}

Bronchopulmonary dysplasia (BPD) is the most common chronic respiratory disease in premature infants but its pathophysiological mechanisms are not completely determined. BPD appears to be a multifactorial disease resulting from the combination of environmental and genetic factors in immature lungs (12). Whereas the nature and the role of environmental factors are well determined, to our knowledge, no study thoroughly investigated the role of genetic factors from the identification of the loci of susceptibility to the function of the encoded protein. By performing the first genome wide association study in a population of very preterm neonates, we previously identified 2 single nucleotide polymorphisms (SNP) in SPOCK2 significantly associated to BPD defined by the need for supplemental oxygen at 36 weeks post-menstrual age (11). SPOCK2 (SPARC/osteonectin, CWCV, and Kazal-like domains proteoglycan 2), also known as Testican-2, is a member of the testican group of extracellular chondroitin and heparin sulfate proteoglycans. Its role has mainly been explored in the central nervous system $(26,28)$. We previously showed that Spock2 was expressed in the developing rat lung with an increasing mRNA expression very close to the beginning of alveolarization and that its expression was increased in lungs from rat pups exposed to hyperoxia (11). We also showed that Spock2 was synthetized by lung fibroblasts and epithelial cells and then deposits throughout the extracellular matrix (ECM), including the basement membrane (11). Spock2 interacts with matrix metalloproteinases (MMP) 14 and 16 (20) that were respectively shown to play a key role in lung development $(4,5)$ and to be associated to the risk of BPD (10). Thus, Spock1 and Spock3 inhibit the proteolysis by MMP14 and MMP16 of pro-MMP2 into its active form. Spock2 abolishes this inhibition by binding to the $\mathrm{COOH}$ terminal domain of Spock3 through its NH2-terminal unique domain (20). In the developing lung, MMP2 acts as a major protease during secondary septation. 
Nevertheless, the exact role of Spock2 during lung development is not determined and it is not known whether it is mediated by the activation of MMP2.

To better understand the role of Spock2 in alveolar development impairment, we designed two mouse models, one that uses a specific anti-Spock 2 antibody and one that reproduces the hyperoxia-induced Spock2 expression with a transgenic mouse model resulting in a conditional and lung-targeted over-expression of Spock2. 


\section{MATERIALS AND METHODS}

\section{Ethical approval}

Ethical approval for all animal experimentation was obtained from the local ethics committee ( $\mathrm{N}^{\circ}$ 12-059, ComEth Afssa/ENVA/UPEC, Maisons-Alfort, France). Animals were housed in the transgenic animal facility at the Institut Henri Mondor de Recherche Biomédicale (IMRB) and transferred to the plateforme d'exploration fonctionnelle du petit animal of the IMRB for experiments.

\section{Antibody model}

The aim of this model was to study the effect of the inhibition of Spock2 by a specific antibody on lung development under physiologic and hyperoxic conditions. Wild-type C57B16J mouse pups and a goat anti-mouse Spock2 antibody (product \# AF2328, R\&D systems, Lille, France) were used. First, to determine the dose and the number of injections needed, antibodies' concentrations in mouse lungs were measured following an intraperitoneal injection of 2 or $5 \mathrm{mg} / \mathrm{kg}$ of the antibody. Briefly, P10 mouse pups were treated and then euthanized at $24 \mathrm{~h}, 48 \mathrm{~h}$ and $72 \mathrm{~h}$ after the antibody administration by intraperitoneal injection of a mixture of $10 \%$ ketamine (Merial, Lyon, France) and 10\% xylazine (Bayer, Puteaux, France) in physiological saline. Lungs were extracted, frozen and then homogenized, and total proteins were extracted. Goat IgG concentrations were then measured using the Goat IgG ELISA Kit (Alpha Diagnostic International, San Antonio, Texas, USA). Second, to determine the localization of the antibody in lung parenchyma, immunohistochemistry using the RTU Vectastain PK7800 kit (Vector Laboratories, Burlingame, CA, USA) that detect goat IgG was performed on P10 mouse lungs $6 \mathrm{~h}$ after an intra-peritoneal injection of either $5 \mathrm{mg} / \mathrm{kg}$ of anti-Spock 2 antibody, $5 \mathrm{mg} / \mathrm{kg}$ of control goat IgG or PBS. The control goat IgG was used as a control for the anti-Spock2 antibody specificity. Once the dose was determined and the 
presence of the specific antibody in the lung parenchyma was confirmed, mouse pups were treated at P5, P8 and P11 by an intra-peritoneal injection of $5 \mathrm{mg} / \mathrm{kg}$ of the specific antibody diluted in PBS, or an intra-peritoneal injection of $5 \mathrm{mg} / \mathrm{kg}$ of the control goat $\mathrm{IgG}$, or by an

intra-peritoneal injection of PBS alone (negative control). Pups were then euthanized as described above at P14 and the lungs were extracted. Tissues were immediately placed in liquid nitrogen and kept at $-80^{\circ} \mathrm{C}$ until RNA or proteins extractions, or fixed with $10 \%$ prefiltered formalin at a constant hydrostatic pressure of $25 \mathrm{~cm} \mathrm{H}_{2} \mathrm{O}$ for at least 20 minutes for evaluation of morphometry and immunohistochemistry.

\section{Transgenic model}

We designed a Knock-In at Rosa26 locus, with a construction similar to the one that we successfully used for over-expression of the gene FGF18 (9), and that have been extensively described by Whitsett et al (32). For the targeting vector construct, the mouse Spock2 cDNA was placed under the control of the (teto)7CMV promoter. Polyadenylation sequences from the bovin growth hormone were used to ensure transcript termination. A hygromycin cassette flanked by FRT sites was introduced as a selection marker downstream of the Spock2 cDNA. Two Homology arms for the Rosa26 Locus were used. The targeting constructs were introduced by electroporation into embryonic stem cells from the 129/SV mouse strain and selected on plates containing hygromycin. Appropriate clones were identified by PCR and confirmed by Southern blot analysis with $5^{\prime}-3$ 'and an internal probe. A karyotype and the sequencing of the homologous recombinant clones have been done. Stem cells carrying the constructs were injected onto blastocysts from C57BL/6 N mice, to obtain chimeric mice. After germline transmission, the generated Spock2 KI mice were initially crossed with a germline Flp-deleter murine line to eliminate the hygromycin cassette and then were bred to SP-C-rtTA mice in which the expression of the rtTA activator construct is targeted on 
alveolar epithelial type II cells by the promoter of surfactant protein (SF)-C (Figure 1). This provided double transgenic mice that were heterozygous for each transgene, thus permitting to conditionally induce the expression of Spock2 in the lung. Genotyping was performed on DNA extracted from mouse tails by use of the Charges Switch gDNA kit Mini Tissue kit from Invitrogen (Cergy-Pontoise, France) using adequate primers for PCR in a Biometra thermocycler for SP-C-rtTA, 5'-GACACATATAAGACCTGGTCA-3' (forward) and 5'AAAATCTTGCCAGRCTTCCCC-3' (reverse) and for (teto)7-Spock2, 5',

ACTTGCTCTCCCAAAGTCGCTCTGAG $3^{\prime}$ (forward) and
TACCTTtTGAtAagGCTGCAGAAGGA 3' (reverse). Spock2 over-expression in mice pups was induced by adding doxycycline $(1 \mathrm{mg} / \mathrm{ml})$ to the drinking water of the mother from P0 to P14.

\section{Hyperoxic model}

Exposure to hyperoxia induces alveolar growth disorders in newborn mice. Mice pups and their dams were placed in Plexiglas exposure chambers (Charles River, France) and exposed in parallel to $85 \%$ or $21 \%$ (room air) $\mathrm{FiO} 2$ from $\mathrm{P} 3$ to P14. The oxygen concentration was regularly monitored. Because adult mice have limited resistance to high oxygen, the dams were switched daily between $\mathrm{O}_{2}$-exposed and room air-exposed litters. The chambers were opened 20 minutes every day to switch the dams and clean the cages. On P14, the pups were euthanized as described above and the lungs were extracted. Tissues were immediately placed in liquid nitrogen and kept at $-80^{\circ} \mathrm{C}$ until RNA or proteins extractions, or fixed with $10 \%$ prefiltered formalin at a constant hydrostatic pressure of $25 \mathrm{~cm} \mathrm{H}_{2} \mathrm{O}$ for at least 20 minutes for evaluation of morphometry and immunohistochemistry. For all experiments, double transgenic mice were compared to SP-C-rtTA simple transgenic mice that did not overexpressed Spock2 and were referred as control mice. 
RNA isolation, Reverse Transcription and real-time quantitative PCR (RT-qPCR)

Total RNA was extracted from lung tissue using the RNeasy Protect Mini kit (Qiagen, France) and reverse transcribed (RT) into cDNAs using $2 \mu \mathrm{g}$ of total RNA, Superscript III reverse transcriptase, random hexamer primers (Invitrogen, France) according to the supplier's protocol. Real-time PCR was performed on QuantStudio ${ }^{\text {TM }} 6$ device (Applied Biosystems, France) using initial denaturation $\left(2 \mathrm{~min}\right.$ at $\left.95^{\circ} \mathrm{C}\right)$, then two-step amplification program $\left(1 \mathrm{~s}\right.$ at $95^{\circ} \mathrm{C}$ followed by $30 \mathrm{~s}$ at $\left.60^{\circ} \mathrm{C}\right)$ repeated 40 times. Melt curve analysis was used to check that a single specific amplified product was generated. Reaction mixtures consisted of 10 ng cDNA, SYBR Green 2X PCR Master Mix (Applied Biosystems, France) and forward and reverse primers for the various examined transcripts (displayed in Table 1). Real-time quantification was achieved by measuring the increase in fluorescence caused by SYBR Green dye binding to double-stranded DNA at the end of each amplification cycle. Relative expression was determined by using the $\Delta \Delta \mathrm{Ct}$ (threshold cycle) method of normalized sample $(\Delta \mathrm{Ct})$ in relation to the expression of a calibrator sample used to normalize data from one plate to another, according to the manufacturer's protocol. Each PCR included a no-template control and a sample without reverse transcriptase. All measurements were performed in triplicates. Hprt mRNA was used as reference.

\section{Lung immunohistochemistry: expression of Spock2 in lung tissue}

Immunostaining of P14 lung tissue was performed using $5-\mu \mathrm{m}$ paraffin sections that were deparaffinized with xylene, rehydrated gradually with graded alcohol solutions and washed with deionized water. Antigens were unmasked by boiling for 20 minutes in $10 \mathrm{mM}$ citric acid buffer $\mathrm{pH}$ 6. After cooling at room temperature, sections were rinsed in phosphate-buffered saline (PBS), pH 7.4 (Sigma) and blocked with 2.5\% normal goat serum for 20 minutes at 
$37^{\circ} \mathrm{C}$. Then sections were incubated overnight at $4^{\circ} \mathrm{C}$ in a humidified chamber with a diluted anti-Spock2 rabbit polyclonal antibody (1:300, bs-11966R, Clinisciences, Nanterre, France). After overnight incubation, sections were washed in PBS and endogenous peroxidase was quenched with $3 \% \mathrm{H}_{2} \mathrm{O}_{2}$ for 30 minutes at room temperature. Sections were then incubated with goat biotinylated secondary antibody (1:300, BA-1000, Vector Laboratories) for 30 minutes, followed by the same time of incubation in the Vectastain $\mathrm{ABC}$ reagent (Vector Laboratories) according to the supplier's protocol. After further washing, chromogen 3,3'diaminobenzidine tetrachloride/nickel-cobalt substrate was applied, yielding a brown colored reaction product, and sections were counterstained with hematoxylin (Hematoxylin QS, Vector Laboratories). Light microscopy images were captured using a digital camera. Quantitative analysis was done with self-written Fiji macros in z-thru projection images of ULP (25). Quantification of protein expression was defined by the surface in relation with the number of nuclei.

\section{Lung morphometry}

Methods used in this study have been described in detail previously (9). Briefly, lung fixation was performed by tracheal infusion of $10 \%$ pre-filtered formalin at constant $25 \mathrm{~cm} \mathrm{H}_{2} \mathrm{O}$ pressure, and fixed lung volume was measured by fluid displacement. After routine processing and paraffin embedding, $5-\mu$ m-thick mediofrontal sections through both lungs were stained with hematoxylin and eosin for morphometry. Alveolar airspace, airways, blood vessels larger than $20 \mu \mathrm{m}$ in diameter, interstitial tissue volume densities and the alveolar surface density were determined using the point counting and mean linear intercept methods (31). Light microscope fields were quantified at an overall magnification of x330 on 20 fields per animal (10 per lung) with a systematic sampling method from a random starting point. All morphometric analyses were performed by a single observer (MLFM) who was unaware of 
group assignment. Alveolar surface density $(\operatorname{Sv}(a, p))$ was determined using point counting and mean linear intercept (MLI) methods described by Weibel. Absolute surface area (Sa) per lung was calculated by multiplying surface density by lung volume. Radial alveolar count (RAC) was performed according to Emery's method (7).

\section{Zymography analysis of total gelatinase activity}

Lung tissues were homogenized in a buffer (Tris-NaCl-CaCl2-triton) at $\mathrm{pH} 7.6$ (8). The supernatant was subjected to electrophoresis in $8 \%(\mathrm{wt} / \mathrm{vol})$ polyacrylamide gels containing 1 $\mathrm{mg} / \mathrm{ml}$ gelatin with sodium dodecyl sulfate (SDS-PAGE; Sigma-Aldrich, Saint-Louis, USA), under non reducing conditions. After electrophoresis, the gels were washed in Triton X-100 $2.5 \%$ for $1 \mathrm{~h}$, rinsed briefly, and incubated at $37^{\circ} \mathrm{C}$ for $72 \mathrm{~h}$ in buffer containing $100 \mathrm{mM}$ TrisHCl, $\mathrm{pH} 7.40$, and $10 \mathrm{mM} \mathrm{CaCl}{ }_{2}$. The gels were then stained with Coomassie brilliant blue R250 and restained in a solution of 7.5\% acetic acid and 5\% methanol. Zones of enzymatic activity were indicated by negative staining: areas of proteolysis were seen as clear bands against a blue background. Enzyme activities in the gel were quantitated using G:Box (Syngene, Synoptics, Cambridge, UK). Relative expression was determined by the method for normalized samples relative to a calibrator sample. Results were expressed as arbitrary units (AU) per $65 \mathrm{~h}$ per $30 \mu \mathrm{g}$ of Bactine in the lung tissue.

\section{Statistical analyses}

Data were expressed as medians with their interquartile range. Multiple groups' comparisons were performed by Kruskal-Wallis analysis, and two-group comparisons were performed by Mann-Whitney U test using GraphPad Prism software (GraphPad software INC, San Diego, CA). A p value $<0.05$ was considered significant. 


\section{RESULTS}

\section{Antibody model}

Development of the model

Twenty-four hours after an intra-peritoneal injection of $5 \mathrm{mg} / \mathrm{kg}$ of anti-Spock 2 antibody in P10 mouse pups, concentration of goat $\mathrm{IgG}$ in lungs was measured at $121 \mathrm{ng} / \mathrm{mg}$ of total protein content. Residual concentrations were measured at 46.1 and $47 \mathrm{ng} / \mathrm{mg}$ of total protein content $48 \mathrm{~h}$ and $72 \mathrm{~h}$ after the injection respectively (supplemental Figure 1). For the $2 \mathrm{mg} / \mathrm{kg}$ dose, concentration at $24 \mathrm{~h}$ was very low $(54.4 \mathrm{ng} / \mathrm{mg})$. Therefore we chose the dose of 5 $\mathrm{mg} / \mathrm{kg}$ for the following experiments.

Six hours after an intra-peritoneal injection of either anti-Spock antibody, control goat IgG or PBS in P10 mouse pups, lungs' immunohistochemistry revealed that the anti-Spock2 antibody was fixed in lung parenchyma whereas control goat $\mathrm{IgG}$ remained exclusively in the intravascular bed (Figure 2). No signal was detected after PBS injection.

\section{Treatment with anti-Spock2 antibodies partially protects from hyperoxic injury}

As hyperoxia exposure led to an over-expression of Spock2, we assessed in wild-type animals whether inhibition of Spock2 by a specific antibody will have an effect on alveolarization, either in room air or after hyperoxia exposure. In control animals injected with PBS, hyperoxia exposure led to alveolar disruption with larger and fewer alveoli as shown by a increased MLI that reflects a diminution in septa's number and a decreased in alveolar surface (Sa and $\operatorname{Sv}(\mathrm{a}, \mathrm{p})$ ) (Figure 3). Treatment with anti-Spock2 antibodies did not modify morphometric parameters when mice were bred in room air (Figure 3). When mice were bred under hyperoxic conditions, treatment with anti-Spock2 antibodies significantly improved alveolarization with a decreased MLI $(\mathrm{p}=0.024)$, and increased values of $\mathrm{S}_{\mathrm{v}(\mathrm{a}, \mathrm{p})}(\mathrm{p}=0.015)$ and $\mathrm{S}_{\mathrm{a}}(\mathrm{p}=0.026)$ as compared to animals exposed to hyperoxia injected with PBS (Figure 3). 
Nevertheless, treatment with anti-Spock2 antibodies under hyperoxic conditions did not completely restore a normal alveolar development as suggested by the significant differences in morphometric analyses between mice bred in room air without treatment and mice bred under hyperoxic conditions that were injected with anti-Spock2 specific antibodies (Figure 3). Treatment with the control goat IgG did not alter morphometric parameters in comparison with injection with PBS, not in room air neither after hyperoxia exposure (Figure 3).

\section{Effect of anti-Spock2 antibodies on Mmp2 activation}

As Spock 2 was shown to abrogate the inhibition of mmp14 and 16 by Spock1 and Spock 3 for the proteolysis of pro-mmp2 in its active form in vitro (20), we studied the activation of mmp2 after treatment with anti-Spock2 antibodies in room air $(n=8)$ and under hyperoxic conditions $(n=6)$. As previously reported in the literature $(13,22)$, in control mice (injected with PBS), hyperoxia exposure led to a significant diminution of the activated fraction of mmp2 (21.8 \% in room air versus $4.9 \%$ after hyperoxic exposure, $\mathrm{p}=0.0002$ Figure 4$)$. AntiSpock2 antibody injection led to a decrease of the activated fraction in room air $(21.8 \%$ in animals injected with PBS versus $12.6 \%$ in animals injected with anti-Spock2 antibody, $\mathrm{p}=0.0027$ Figure 4). There were no significant differences for the activated fraction of Mmp2 between animals injected with PBS and animals injected with the antibody under hyperoxic conditions.

Anti-Spock2 antibodies does not alter the expression of main players in alveolar development Expression of known players in alveolar development was quantified by RT-qPCR in the different experimental conditions. Expression of those genes was significantly decreased in control animals after exposure to hyperoxia as compared to control animals bred in room air (Figure 5). Hyperoxia had the same effect in animals treated with the anti-Spock2 antibody, as 
compared to animals treated with the anti-Spock2 antibody bred in room air (Figure 5). Nevertheless, no significant difference was observed between control animals and animals treated with the anti-Spock2 antibody, either in room air or after hyperoxia exposure for any of the genes that were studied (Figure 5).

\section{Transgenic model}

Spock2 expression

Spock2 expression was quantified in double-transgenic mice $(n=9)$ and controls $(n=5)$ by RTqPCR at P14. Spock2 expression was significantly increased in double transgenic mice $(n=9)$ as compared to controls $(n=5)$ with a median 30 -fold increase $(p=0,001)$. At the protein level, Spock2 expression was quantified by immunohistochemistry at P14. Immunostaining was significantly more intense in double transgenic mice $(n=5)$ than in controls $(n=7)(p=0,048)$ (Figure 6).

Lung over-expression of Spock2 altered alveolar development in pups bred in room air and worsened hyperoxia-induced lesions

Morphology of lung parenchyma was analyzed at P14 from control and transgenic mice bred either in room air or under hyperoxic conditions. In room air, Spock2 over-expression induced significant alterations in alveolarization with an increased mean linear intercept (MLI) (156 versus $137, \mathrm{p}=0.018)$, a decreased alveolar area density $\left(\mathrm{S}_{\mathrm{v}(\mathrm{a}, \mathrm{p})}\right)(276$ vs 319, $\mathrm{p}=0.011)$, and a decreased absolute area of airspaces $\left(\mathrm{S}_{\mathrm{a}}\right)(52$ vs 82, $\mathrm{p}=0.018)$ in double transgenic mice $(\mathrm{n}=5)$ as compared to controls $(n=14)$ (Figure 7). These alterations in morphometric parameters reflect a disruption in alveolar development with fewer and larger alveoli as shown in panel 1.B as compared to panel 1.A in Figure 7. As expected in control animals (24), hyperoxia exposure altered alveolar development with an increased MLI (173.5 vs 137, p<0.0001), and 
decreased values of $\mathrm{S}_{\mathrm{v}(\mathrm{a}, \mathrm{p})}(241$ vs 319, $\mathrm{p}<0.0001)$, specific alveolar area density $\left(\mathrm{S}_{\mathrm{v}(\mathrm{a}, \mathrm{p}) \mathrm{spec}}\right)$ (3529 vs 5585, $\mathrm{p}<0.0001), \mathrm{S}_{\mathrm{a}}(66.5$ vs 82, $\mathrm{p}=0.002)$, specific absolute surface area of airspaces $\left(\mathrm{S}_{\mathrm{a} \text { spec }}\right)(949$ vs 1471, $\mathrm{p}=0.0004)$ and radial alveolar count $(\mathrm{RAC})(7.65$ vs $9.64 \mathrm{p}=0.04)$ as compared to controls in room air (Figure 7 panel 2 and panel 1.C versus panel 1.A). After exposure to hyperoxia, double transgenic mice $(\mathrm{n}=6)$ displayed aggravated alveolar lesions as compared to control mice ( $\mathrm{n}=6)$, with an increased MLI (213 vs $173.5 \mathrm{p}=0.026)$, and decreased values of $\mathrm{S}_{\mathrm{v}(\mathrm{a}, \mathrm{p})}(204$ vs $241 \mathrm{p}=0.026)$ and $\mathrm{S}_{\mathrm{v}(\mathrm{a}, \mathrm{p}) \text { spec }}(2965$ vs $3529 \mathrm{p}=0.041)$ (Figure 7 panel 2 and panel 1.D versus panel 1.C).

Alveolar lesions induced by Spock2 over-expression are not associated to an increased activation of Mmp2

We studied the activation of mmp2 in our models ( $n=6$ per group). As previously reported in the literature $(13,22)$, in control mice, hyperoxia exposure led to a significant diminution of the activated fraction of mmp2 $27.1 \%$ in room air versus $12.6 \%$ after hyperoxic exposure, $\mathrm{p}=0.002$, Figure 8). Nevertheless, there were no difference for the activated fraction of $\mathrm{mmp} 2$ between double transgenic mice and control mice either in room air or after exposure to hyperoxia $(21.5 \%$ vs $27.1 \%$ in room air, $\mathrm{p}=0.48$ and $14.3 \%$ vs $12.6 \%$ under hyperoxic conditions, $\mathrm{p}=0.24$, Figure 8 ).

SPOCK2 over-expression does not alter the expression of main players in alveolar development

To further investigate the mechanisms by which over-expression of Spock2 alters alveolar development, expression of known players in alveolar development was quantified by RTqPCR in the different experimental conditions. For control animals, expression of Fgfr4 and 
$P d g f r$ were significantly lower in animals bred under hyperoxic conditions as compared to animals bred in room air. For transgenic mice, expression of Vegfa, Fgfr4, Pdgfr and Tgfß were significantly lower in animals bred in hyperoxic conditions. Nevertheless, no significant difference was observed between double transgenic and control mice either in room air or after hyperoxia exposure for any of the genes that were studied (Figure 9).

\section{DISCUSSION}

We previously identified $2 \mathrm{SNP}$ in the SPOCK2 gene that were associated with the development of BPD in a large French cohort of very preterm neonates (11). Our results were independently replicated in a Finnish population (11). Here we report a significant effect of Spock2 over-expression on alveolar development in a mouse transgenic model that conditionally over-expressed Spock2 during alveolarization in lungs of mouse pups. Overexpression of Spock2 led to alterations of morphometric parameters and worsened the lesions that were induced by hyperoxia. Inhibition of the Spock2 protein by a specific antibody partially protects from the hyperoxic aggression. Altogether, these results are in favor of a deleterious effect of Spock2 over-expression on alveolar development especially in a situation of neonatal lung injury and suggest a role of Spock2 in hyperoxia induced lesions. These results are of particular interest in the setting of BPD where hyperoxic aggression is known to play an important role on its subsequent development in preterm babies $(2,16,17)$.

To our knowledge, this work represents the first study in the field of BPD starting from the selection of a locus in a genome-wide association study in humans to the demonstration of the role of the corresponding protein during normal and altered lung development in mice. Four other genome-wide association studies were published $(3,19,27,29)$ and only the study by Ambalvanan et al (3) investigated the expression of the locus that was selected (miR-219) 
during lung development and after hyperoxia exposure in mice. Three exome sequencing studies identified many loci with data of quantitative mRNA expression of the corresponding genes coming from large transcriptomic data sets from human or mice lungs but without any further functional studies on animal models $(6,18,23)$.

SPOCK2, also known as Testican-2, is a member of the testican group of extracellular chondroitin and heparin sulfate proteoglycans that includes 2 others proteins namely Testican1 and Testican-3. Testican family's functions were especially studied in relation to the role and over-expression of MMPs in various human malignancies (21). Indeed, it was first shown that SPOCK1 and 3 inhibit pro-MMP-2 processing mediated by MMP14 and MMP16 and that transfection of SPOCK3 in glioma cells suppressed their invasive growth in collagen gel (21). Further studies demonstrated that SPOCK2 abolishes the inhibition of MMP14 and 16 by SPOCK1 and 3 thus promoting ECM degradation and cell migration and invasion (20). As MMP2, 14 and 16 were shown to play a role during lung development $(4,5,10,15)$, we hypothesized that the role of SPOCK2 in alveolar development could be linked to MMP2 activation. Nevertheless, the hypothesis was not confirmed in our model as there was no significant difference in MMP2 activation between control and transgenic mice either in animals bred in room air or after hyperoxia exposure.

Spock2 over-expression did not alter the expression of several genes that were selected for their roles in alveolar development or the inflammatory response that is triggered by environmental aggressions in the setting of BPD.

Therefore, our results did not bring the mechanism by which SPOCK2 could have a deleterious effect on alveolarization in the setting of a hyperoxic aggression. It appears that it is neither mediated by MMPs activities and ECM remodeling, nor by the main players involved in alveolar development. A recent study identified SPOCK2 as a marker of the early transdifferentiation from alveolar type 2 (AT2) to alveolar type 1 (AT1) epithelial cells (14). 
In a whole genome analysis, SPOCK2 was found to be rapidly highly expressed when AT2 cells were cultured on collagen (that promotes transdifferentiation into AT1) whereas its level of expression did not change when AT2 cells were cultured on Matrigel (that retarded transdifferentation) (14). Furthermore, AT2 cells act as AT1 cells progenitors during development (1) but also after lung injury (30). When considering SPOCK2 as a marker of AT1 cells, its over-expression in a setting of lung injury during development could impair the balance between AT2 and AT1 cells and prevent AT2 cells from their role of progenitors and actors during secondary septation and repairs after epithelial injury such as hyperoxia. In the specific setting of BPD that results in part from aggressions occurring in the developing lungs, the over-expression of SPOCK2 could be associated with a preferred transdifferentiation from AT2 into AT1 cells. This imbalance in favor of AT1 cells would limit the capacity of repairs and regeneration in the lungs and participate to BPD development.

In conclusion, by performing morphometric analyses of transgenic and control mice lungs, we bring strong arguments for the deleterious role of SPOCK2 on lung alveolar development especially after lung injury, suggesting its role in BPD susceptibility. This effect could be mediated by the imbalance between AT2 and AT1 cells with a lack of sufficient AT2 cells to pursue cell proliferation and repair that are necessary to secondary septation and formation of the definitive alveoli. This hypothesis will need further studies to be confirmed. 


\section{References}

1. Adamson IY, Bowden DH. Derivation of type 1 epithelium from type 2 cells in the developing rat lung. Lab Investig J Tech Methods Pathol 32: 736-745, 1975.

2. Akram Khan M, Kuzma-O'Reilly B, Brodsky NL, Bhandari V. Site-specific characteristics of infants developing bronchopulmonary dysplasia. $J$ Perinatol 26: 42835, 2006.

3. Ambalavanan N, Cotten CM, Page GP, Carlo WA, Murray JC, Bhattacharya S, Mariani TJ, Cuna AC, Faye-Petersen OM, Kelly D, Higgins RD, Genomics and Cytokine Subcommittees of the Eunice Kennedy Shriver National Institute of Child Health and Human Development Neonatal Research Network. Integrated genomic analyses in bronchopulmonary dysplasia. J Pediatr 166: 531-537.e13, 2015.

4. Atkinson JJ, Holmbeck K, Yamada S, Birkedal-Hansen H, Parks WC, Senior RM. Membrane-type 1 matrix metalloproteinase is required for normal alveolar development. Dev Dyn 232: 1079-90, 2005.

5. Boucherat O, Bourbon JR, Barlier-Mur AM, Chailley-Heu B, D'Ortho MP, Delacourt C. Differential expression of matrix metalloproteinases and inhibitors in developing rat lung mesenchymal and epithelial cells. Pediatr Res 62: 20-5, 2007.

6. Carrera P, Di Resta C, Volonteri C, Castiglioni E, Bonfiglio S, Lazarevic D, Cittaro D, Stupka E, Ferrari M, Somaschini M, BPD and Genetics Study Group. Exome sequencing and pathway analysis for identification of genetic variability relevant for bronchopulmonary dysplasia (BPD) in preterm newborns: A pilot study. Clin Chim Acta Int J Clin Chem 451: 39-45, 2015.

7. Emery JL, Mithal A. The number of alveoli in the terminal respiratory unit of man during late intrauterine life and childhood. Arch Dis Child 35: 544-547, 1960.

8. Franco M-L, Waszak P, Banalec G, Levame M, Lafuma C, Harf A, Delacourt C. LPS-induced lung injury in neonatal rats: changes in gelatinase activities and consequences on lung growth. Am J Physiol-Lung Cell Mol Physiol 282: L491-L500, 2002.

9. Franco-Montoya M-L, Boucherat O, Thibault C, Chailley-Heu B, Incitti R, Delacourt C, Bourbon JR. Profiling target genes of FGF18 in the postnatal mouse lung: possible relevance for alveolar development. Physiol Genomics 43: 1226-1240, 2011.

10. Hadchouel A, Decobert F, Franco-Montoya ML, Halphen I, Jarreau PH, Boucherat O, Martin E, Benachi A, Amselem S, Bourbon J, Danan C, Delacourt C. Matrix metalloproteinase gene polymorphisms and bronchopulmonary dysplasia: identification of MMP16 as a new player in lung development. PLoS One 3: e3188, 2008.

11. Hadchouel A, Durrmeyer X, Bouzigon E, Incitti R, Huusko J, Jarreau PH, Lenclen R, Demenais F, Franco-Montoya ML, Layouni I, Patkai J, Bourbon J, Hallman M, Danan C, Delacourt C. Identification of SPOCK2 as a Susceptibility Gene for Bronchopulmonary Dysplasia. Am J Respir Crit Care Med ( August 11, 2011). doi: 10.1164/rccm.201103-05480C. 
12. Hadchouel A, Franco-Montoya M-L, Delacourt C. Altered lung development in bronchopulmonary dysplasia: Altered Lung Development in Bpd. Birt Defects Res A Clin Mol Teratol 100: 158-167, 2014.

13. Hosford GE, Fang X, Olson DM. Hyperoxia decreases matrix metalloproteinase-9 and increases tissue inhibitor of matrix metalloproteinase-1 protein in the newborn rat lung: association with arrested alveolarization. Pediatr Res 56: 26-34, 2004.

14. Johansson HM, Newman DR, Sannes PL. Whole-Genome Analysis of Temporal Gene Expression during Early Transdifferentiation of Human Lung Alveolar Epithelial Type 2 Cells In Vitro. PLoS ONE 9: e93413, 2014.

15. Kheradmand F, Rishi K, Werb Z. Signaling through the EGF receptor controls lung morphogenesis in part by regulating MT1-MMP-mediated activation of gelatinase A/MMP2. J Cell Sci 115: 839-48, 2002.

16. Korhonen P, Tammela O, Koivisto AM, Laippala P, Ikonen S. Frequency and risk factors in bronchopulmonary dysplasia in a cohort of very low birth weight infants. Early Hum Dev 54: 245-58, 1999.

17. Laughon MM, Langer JC, Bose CL, Smith PB, Ambalavanan N, Kennedy KA, Stoll BJ, Buchter S, Laptook AR, Ehrenkranz RA, Cotten CM, Wilson-Costello DE, Shankaran S, Van Meurs KP, Davis AS, Gantz MG, Finer NN, Yoder BA, Faix RG, Carlo WA, Schibler KR, Newman NS, Rich W, Das A, Higgins RD, Walsh MC. Prediction of bronchopulmonary dysplasia by postnatal age in extremely premature infants. Am J Respir Crit Care Med 183: 1715-22, 2011.

18. Li J, Yu K-H, Oehlert J, Jeliffe-Pawlowski LL, Gould JB, Stevenson DK, Snyder M, Shaw GM, O'Brodovich HM. Exome Sequencing of Neonatal Blood Spots and the Identification of Genes Implicated in Bronchopulmonary Dysplasia. Am J Respir Crit Care Med 192: 589-596, 2015.

19. Mahlman M, Karjalainen MK, Huusko JM, Andersson S, Kari MA, Tammela OKT, Sankilampi U, Lehtonen L, Marttila RH, Bassler D, Poets CF, Lacaze-Masmonteil T, Danan C, Delacourt C, Palotie A, Muglia LJ, Lavoie PM, Hadchouel A, Rämet M, Hallman M. Genome-wide association study of bronchopulmonary dysplasia: a potential role for variants near the CRP gene. Sci Rep 7: 9271, 2017.

20. Nakada M, Miyamori H, Yamashita J, Sato H. Testican 2 abrogates inhibition of membrane-type matrix metalloproteinases by other testican family proteins. Cancer Res 63: 3364-9, 2003.

21. Nakada M, Yamada A, Takino T, Miyamori H, Takahashi T, Yamashita J, Sato H. Suppression of membrane-type 1 matrix metalloproteinase (MMP)-mediated MMP-2 activation and tumor invasion by testican 3 and its splicing variant gene product, N-Tes. Cancer Res 61: 8896-902, 2001.

22. Porzionato A, Zaramella P, Macchi V, Grisafi D, Salmaso R, Baraldi M, Fornaro E, Tassone E, Masola V, Onisto M, Chiandetti L, De Caro R. Fluoxetine may worsen hyperoxia-induced lung damage in neonatal rats. Histol Histopathol 27: 1599-1610, 2012. 
23. PROP Investigators, Hamvas A, Feng R, Bi Y, Wang F, Bhattacharya S, Mereness J, Kaushal M, Cotten CM, Ballard PL, Mariani TJ. Exome sequencing identifies gene variants and networks associated with extreme respiratory outcomes following preterm birth. BMC Genet 19, 2018.

24. Randell SH, Mercer RR, Young SL. Postnatal growth of pulmonary acini and alveoli in normal and oxygen-exposed rats studied by serial section reconstructions. Am J Anat 186: 55-68, 1989.

25. Schindelin J, Arganda-Carreras I, Frise E, Kaynig V, Longair M, Pietzsch T, Preibisch S, Rueden C, Saalfeld S, Schmid B, Tinevez J-Y, White DJ, Hartenstein V, Eliceiri K, Tomancak P, Cardona A. Fiji: an open-source platform for biological-image analysis. Nat Methods 9: 676-682, 2012.

26. Schnepp A, Komp Lindgren P, Hulsmann H, Kroger S, Paulsson M, Hartmann U. Mouse testican-2. Expression, glycosylation, and effects on neurite outgrowth. J Biol Chem 280: 11274-80, 2005.

27. Torgerson DG, Ballard PL, Keller RL, Oh SS, Huntsman S, Hu D, Eng C, Burchard EG, Ballard RA, TOLSURF Study Group. Ancestry and genetic associations with bronchopulmonary dysplasia in preterm infants. Am J Physiol-Lung Cell Mol Physiol 315: L858-L869, 2018.

28. Vannahme C, Schubel S, Herud M, Gosling S, Hulsmann H, Paulsson M, Hartmann $\mathbf{U}$, Maurer P. Molecular cloning of testican-2: defining a novel calcium-binding proteoglycan family expressed in brain. J Neurochem 73: 12-20, 1999.

29. Wang H, St Julien KR, Stevenson DK, Hoffmann TJ, Witte JS, Lazzeroni LC, Krasnow MA, Quaintance CC, Oehlert JW, Jelliffe-Pawlowski LL, Gould JB, Shaw GM, O'Brodovich HM. A genome-wide association study (GWAS) for bronchopulmonary dysplasia. Pediatrics 132: 290-297, 2013.

30. Warburton D, El-Hashash A, Carraro G, Tiozzo C, Sala F, Rogers O, De Langhe S, Kemp PJ, Riccardi D, Torday J, Bellusci S, Shi W, Lubkin SR, Jesudason E. Lung organogenesis. Curr Top Dev Biol 90: 73-158, 2010.

31. Weibel ER. [Morphometric studies on the growth of gas exchange capacity of the rat lung]. Helv Physiol Pharmacol Acta 24: C56-59, 1966.

32. Whitsett JA, Clark JC, Picard L, Tichelaar JW, Wert SE, Itoh N, Perl A-KT, Stahlman MT. Fibroblast growth factor 18 influences proximal programming during lung morphogenesis. J Biol Chem 277: 22743-22749, 2002. 
Table 1: Sequence of primers used for RT-qPCR determinations

\begin{tabular}{|l|l|l|r|}
\hline Gene Name & \multicolumn{1}{|c|}{ Forward Primer (5'-3') } & \multicolumn{1}{c|}{ Reverse Primer $\left(5^{\prime}-3^{\prime}\right)$} & Amplicon $(\mathrm{pb})$ \\
\hline Hprt & GTTAAGCAGTACAGCCCCAAAATG & TCAAGGGCATATCCAACAACAAAC & 134 \\
\hline Spock2 & ATCAGCCGCAAGAAGTTGGA & CAGAGCTGTAGGTATGGCCG & 139 \\
\hline Fgfr3 & GGAGTTCCACTGCAAGGTG & CCTCTAGCTCCTTGTCGGTG & 155 \\
\hline Fgfr4 & CTGCTTTGGGCAAGTGGTTC & TGCCAAATCCTTGTCGGAGG & 118 \\
\hline Fgf18 & TGAACACGCACTCCTTGCTAGT & GAATTCTACCTGTGTATGAACCGAAA & 76 \\
\hline VegfA & TCTCCCAGATCGGTGACAGT & GGCAGAGCTGAGTGTTAGCA & 71 \\
\hline Pdgfr & GAGCTTTGAGCGACGCC & GACCAGAAAGACCTGGTGGGA & 70 \\
\hline Tgfß1 & GCTAATGGTGGACCGCAAC & ACTGTGTGAGATGTCTTTGGTTTC & 58 \\
\hline
\end{tabular}


Figure legends:

Figure 1: Transgenic constructs used for conditional expression of Spock2

Figure 2: Immunostaining of goat $\mathrm{IgG}$ in mouse lung tissue $6 \mathrm{~h}$ after an intra-peritoneal injection of (A) anti-Spock2 antibody, (B) control goat IgG and (C) PBS. A: immunostaining after one injection of anti-Spock2 antibody shows a diffuse staining in alveolar septa (arrow and inset). B: immunostaining after one injection of control goat IgG shows a staining limited to vessels (arrow). C: no staining was observed after one injection of PBS. Magnification: $\mathrm{x}$ 400.

Figure 3: Effect of treatment with anti-Spock2 antibodies in control mice bred in room air and after hyperoxia exposure. Panel A. Intra-peritoneal injection of a specific antibody that targets Spock2 partially rescued alveolar lesions induced by hyperoxia exposure, whereas in panel B. injection with the control goat $\mathrm{IgG}$ did not alter morphometric parameters either in room air or after hyperoxia exposure Room air injected with PBS (RA/PBS), room air injected with the enti-Spock2 antibody (RA/Ab), hyperoxia exposure injected with PBS (O2/PBS), and hyperoxia exposure injected with the anti-Spock2 antibody (O2/Ab), room air injected with the control goat $\operatorname{IgG}(\mathrm{RA} / \mathrm{IgGc})$, hyperoxia exposure injected with the control goat $(\mathrm{O} 2 / \mathrm{IgGc})$ $*: \mathrm{p}<0.05 ; * *: \mathrm{p}<0.01 ; * * *: \mathrm{p}<0.001$

Figure 4: Zymographic analyses of Mmp2 activation in the antibody model. Activation of Mmp2 was explored by measuring the activated fraction of Mmp2 in the different conditions of the antibody model ie room air injected with PBS (RA/PBS), room air injected with the antibody (RA/Ab), hyperoxia exposure injected with PBS (O2/PBS), and hyperoxia exposure injected with the antibody $(\mathrm{O} 2 / \mathrm{Ab}) . * *: \mathrm{p}<0.01 ; * * *: \mathrm{p}<0.001 ; * * * *: \mathrm{p}<0.0001$.

Figure 5: mRNA expression pattern of different genes involved in alveolar development in the antibody model. Although hyperoxia exposure induced a decrease in gene expression for 
Fgfr3, Fgfr4, Fgf18, Vegfa, Pdgfr and Tgf $\beta$, no significant difference was observed between control animals and animals treated with the anti-Spock 2 antibody, either in room air or after hyperoxia exposure. *:p<0.05; **:p<0.01;***:p<0.001;****p<0.0001

Figure 6: Expression of Spock2 in control and double transgenic mice. A. and B. Immunostaining (brown) of Spock2 in control and double transgenic mice over-expressing Spock2. A: Control mouse. B: Double transgenic mouse. Immunostaining was more intense in double transgenic animals (B) than in controls (A). Quantitative analysis (C) confirmed a significant increase in double transgenic mice as compared to controls. Magnification x 400 . $*: \mathrm{p}<0.05$

Figure 7: Morphometric parameters in control and double transgenic mice bred in room air or under hyperoxic conditions. 1: histologic sections of control (A and $\mathrm{C}$ ) and transgenic (B and D) pups' lungs at P14 after exposition to air (A and B) or oxygen (85\%) (C and D). 2: morphometric analyses comparing genotypes (control (Ctrl) or double transgenic (KI)) under the 2 different experimental conditions (room air (RA) or hyperoxia (O2)) showing altered alveolarization in KI as compared to control animals both in room air and after exposure to hyperoxia. Magnification x 100.*:p<0.05; **:p<0.01; ***:p<0.001;****p<0.0001

Figure 8: Zymographic analyses of MMP2 activation in the experimental groups. As shown by quantitative analysis exposure to hyperoxia induced a decrease in the activation fraction of MMP2 for both genotypes as compared to room air, but over-expression of SPOCK2 did not modify the activation of MMP2. *:p<0.05;**:p<0.01

Figure 9: mRNA expression pattern of different genes involved in alveolar development in the different experimental conditions. Although hyperoxia exposure induced a decrease in gene expression for Fgfr4, Vegfa, Pdgfr and Tgf $\beta$, no significant difference was observed between 
double transgenic and control mice either in room air or after hyperoxia exposure for any of the genes that were studied. *:p<0.05;**:p<0.01;***:p<0.001

\section{ACKNOWLEDGMENTS}

None.

\section{GRANTS}

This study and AH was funded by l'Agence Nationale de la Recherche (ANR-12-BSV10004-01). AH was also funded by the Fonds de Recherche en Santé Respiratoire et de la Fondation du Souffle. SG was funded by la Fondation pour la Recherche Médicale.

\section{DISCLOSURES}

No conflicts of interest, financial or otherwise, are declared by the authors.

\section{AUTHOR CONTRIBUTIONS}

AH, SG, MDC and CD conceived and designed research; AH, MLF, SG and MDC performed experiments; AH, MLF, SG and CD analyzed data; AH, MLF, SG and CD interpreted results of experiments; AH and MLF prepared figures; AH drafted manuscript; AH, MLF and CD edited and revised manuscript; $\mathrm{AH}, \mathrm{MLF}, \mathrm{SG}, \mathrm{MDC}$ and $\mathrm{CD}$ approved final version of manuscript. 


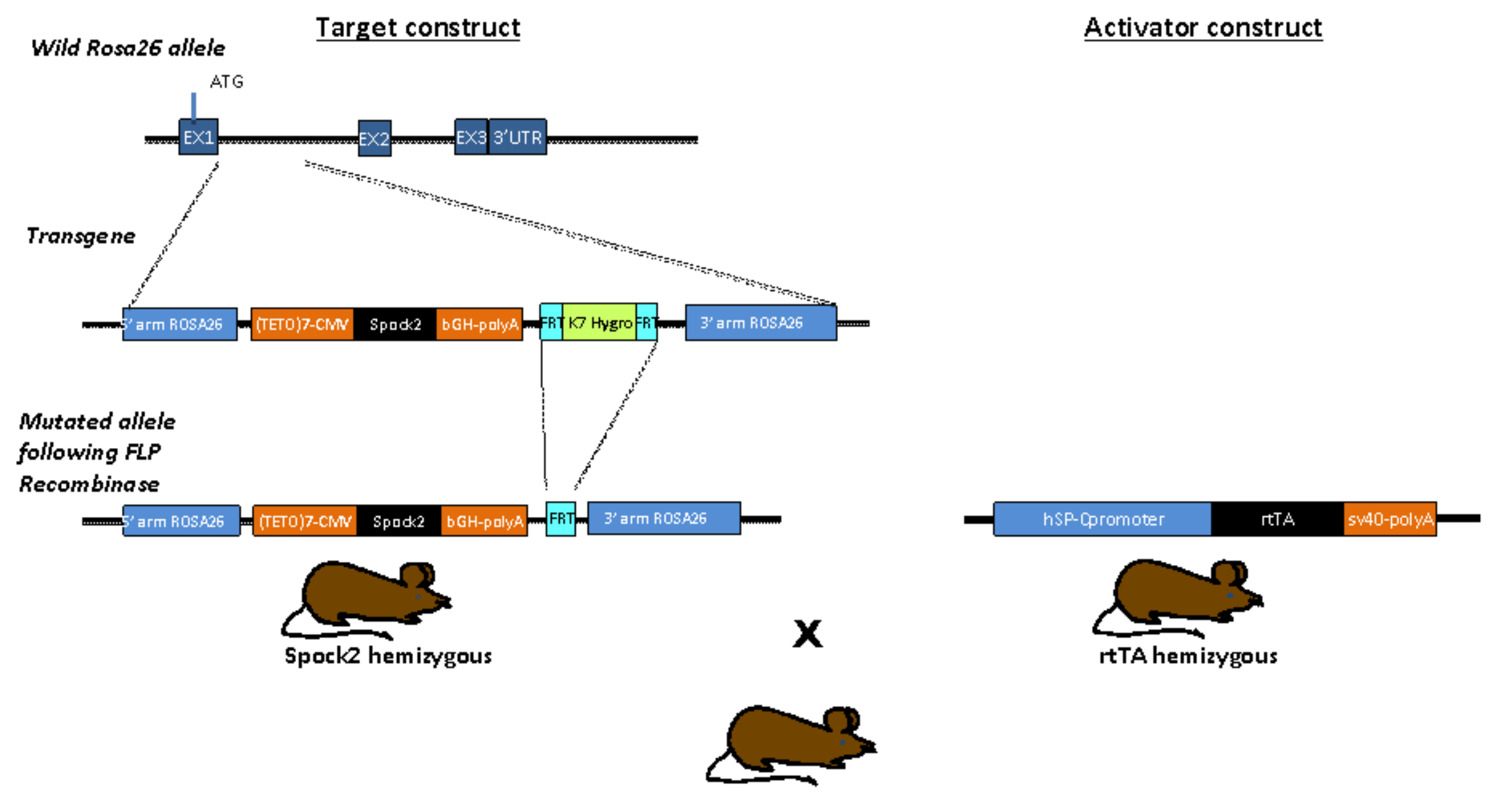

rtTA hemizygous

Spock2 hemizygous 

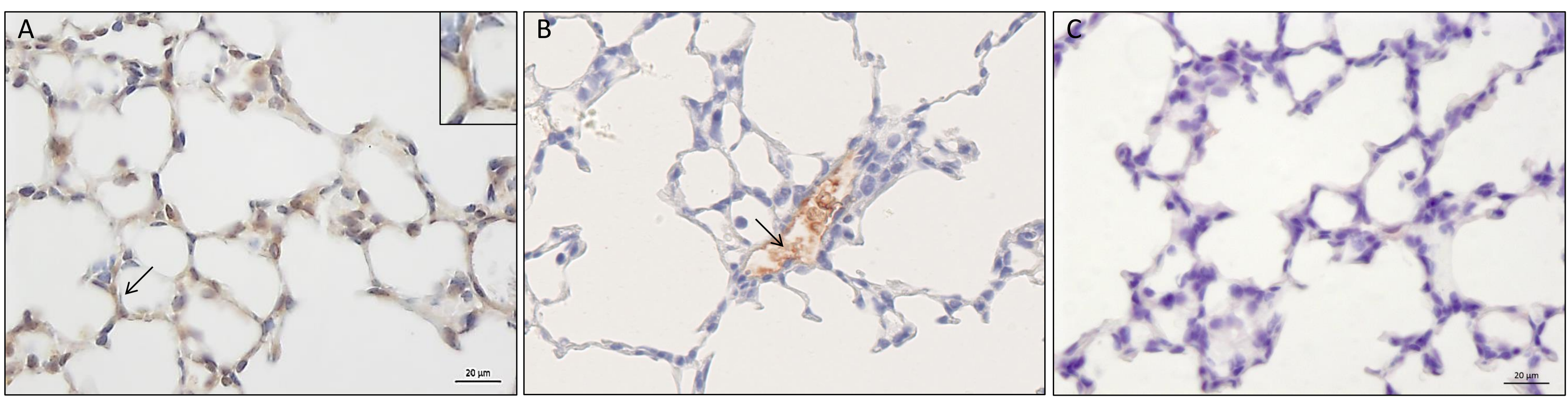

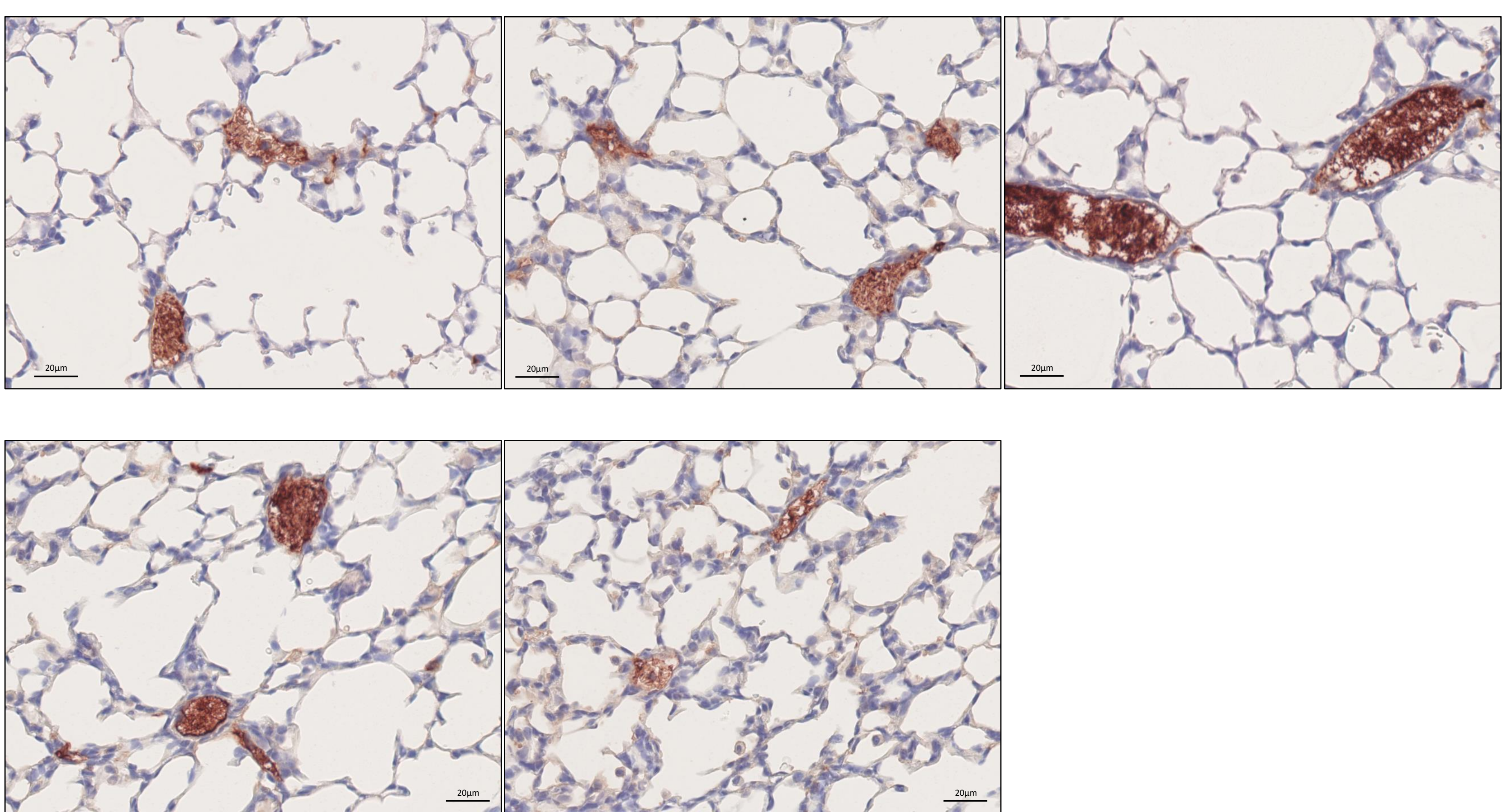

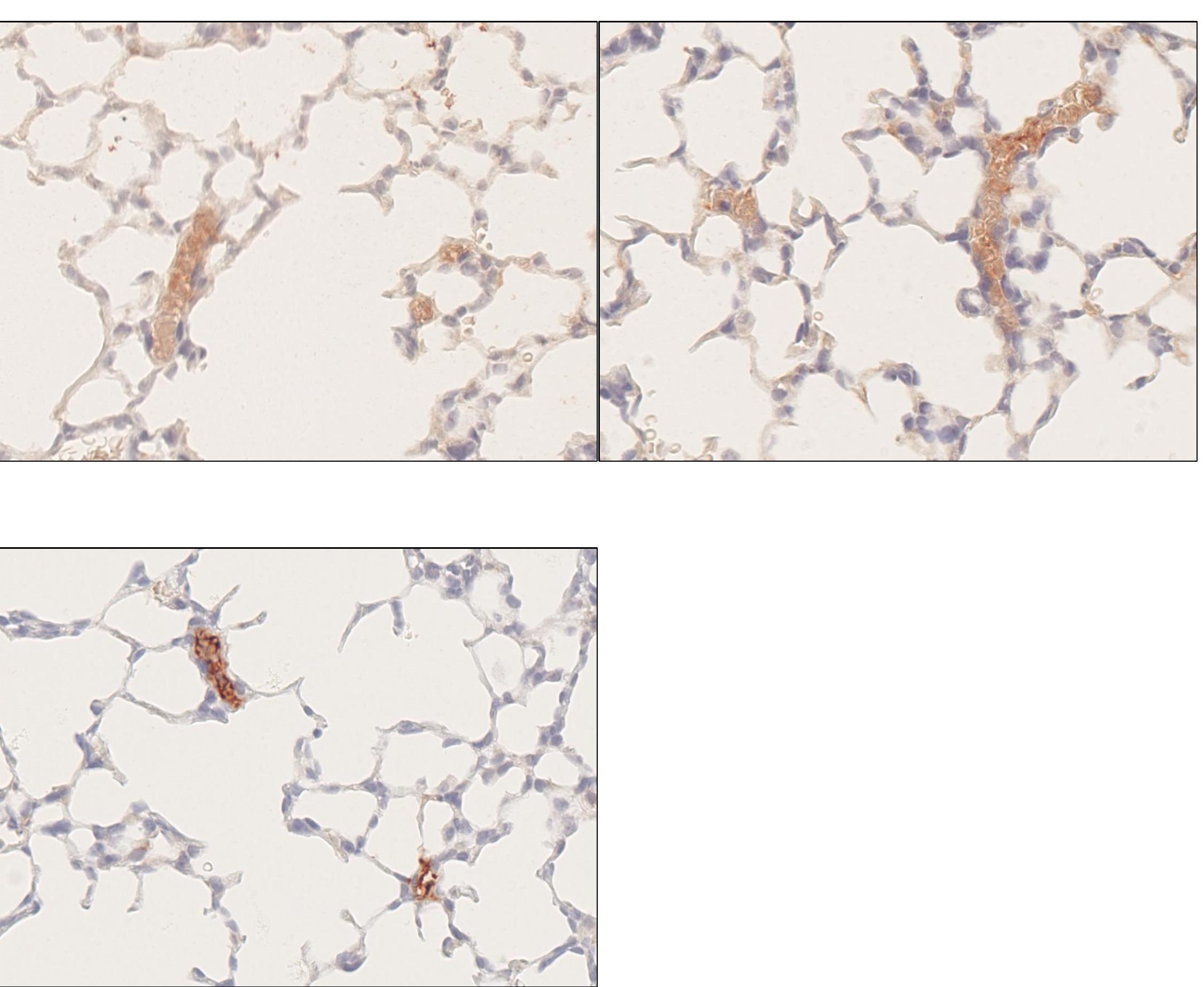

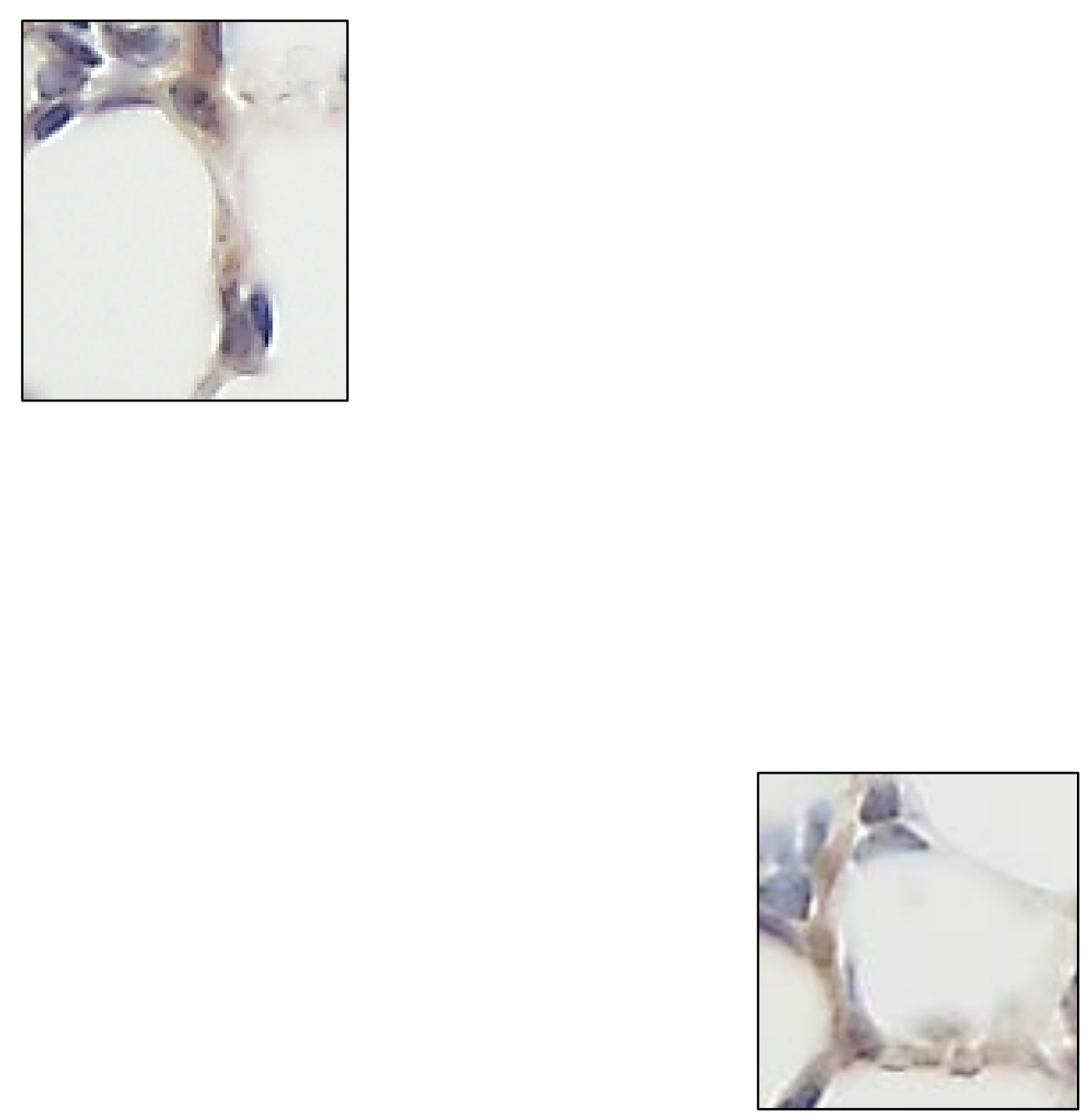
A.

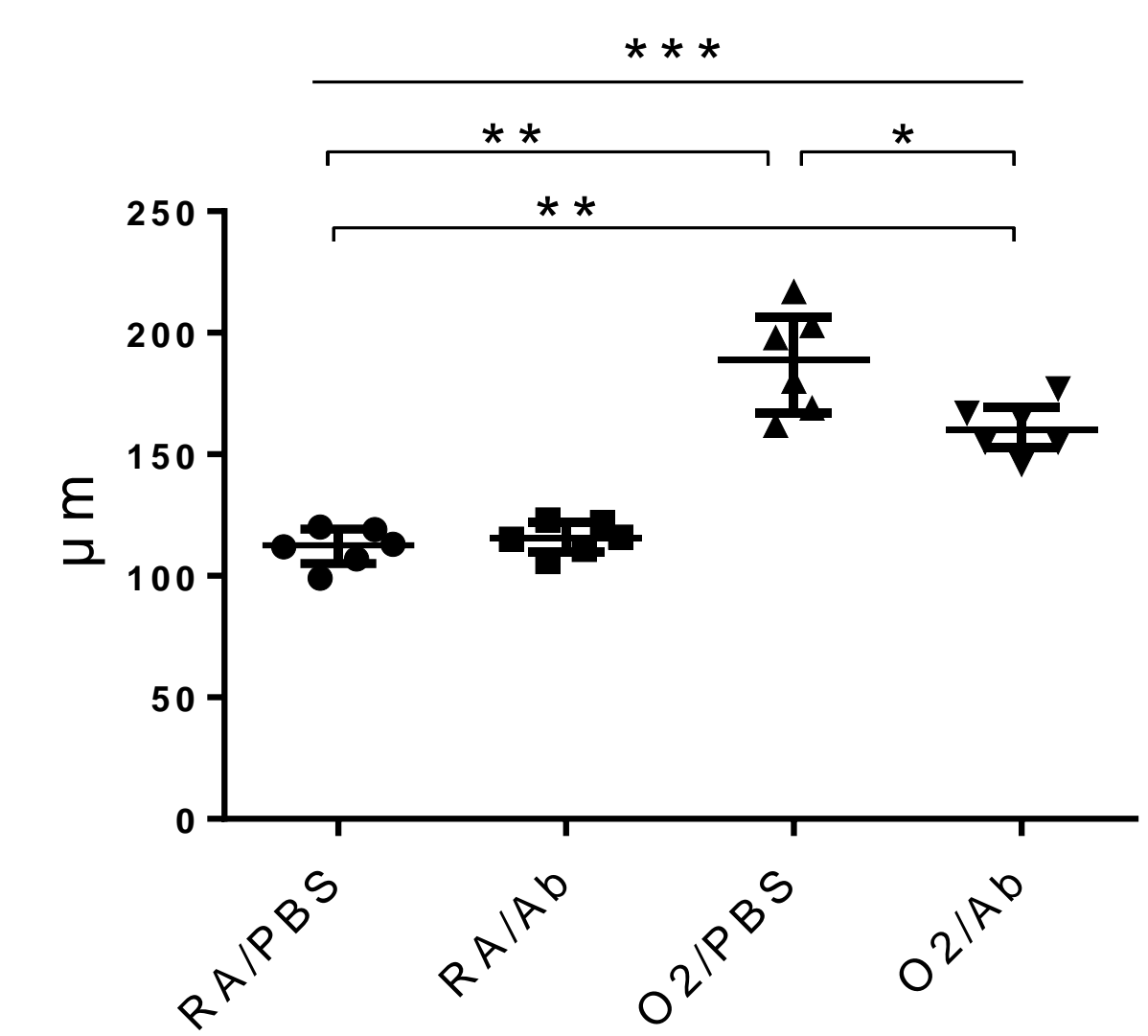

B.

MLI

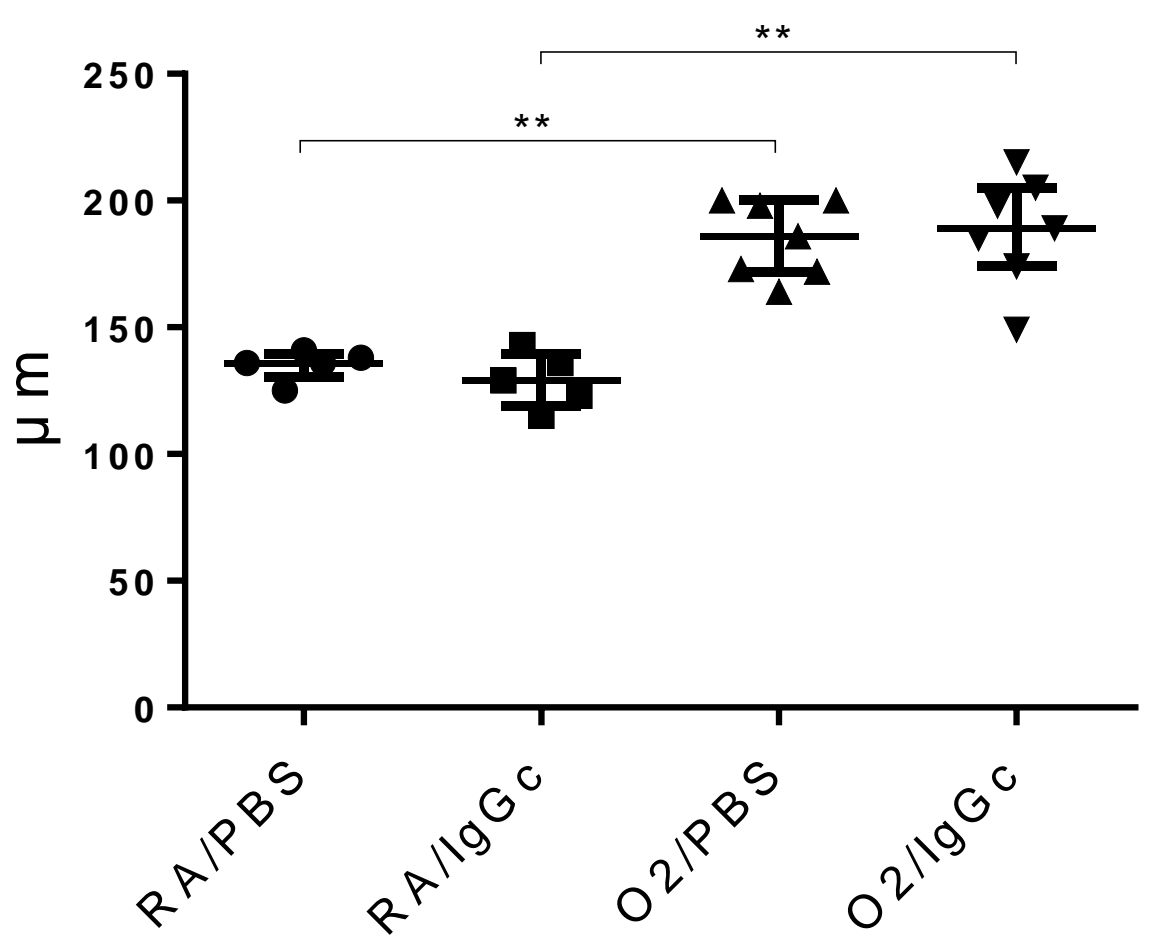

$\operatorname{Sv}(a, p)$

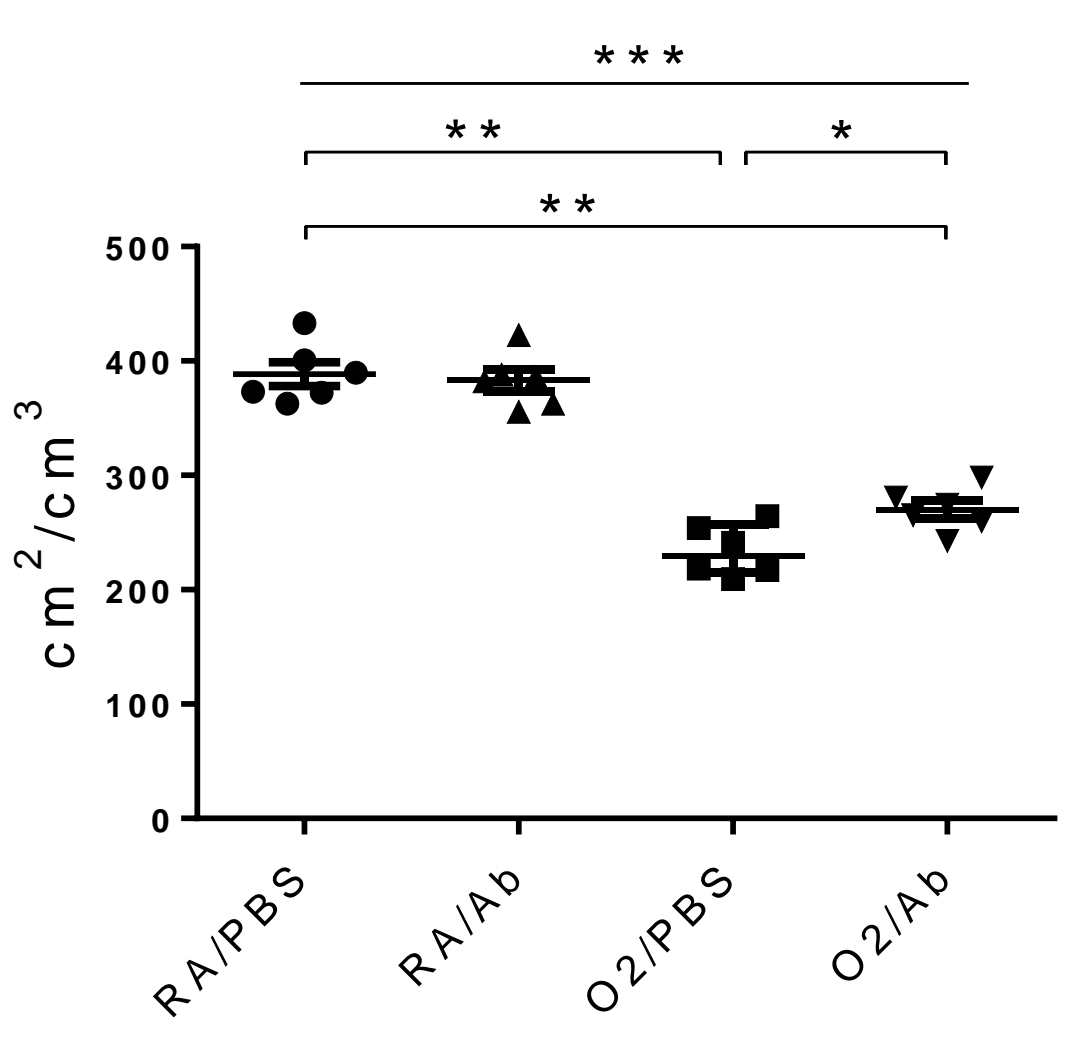

$\operatorname{Sv}(a, p)$

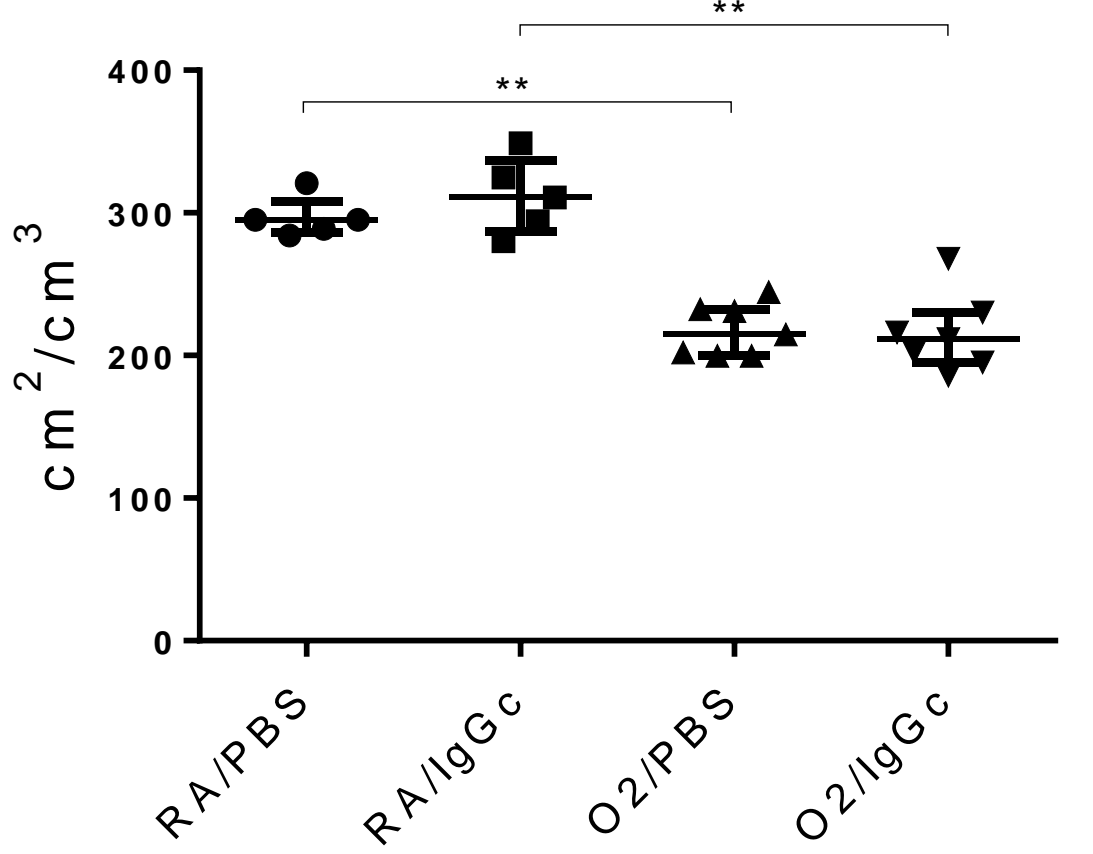

Sa

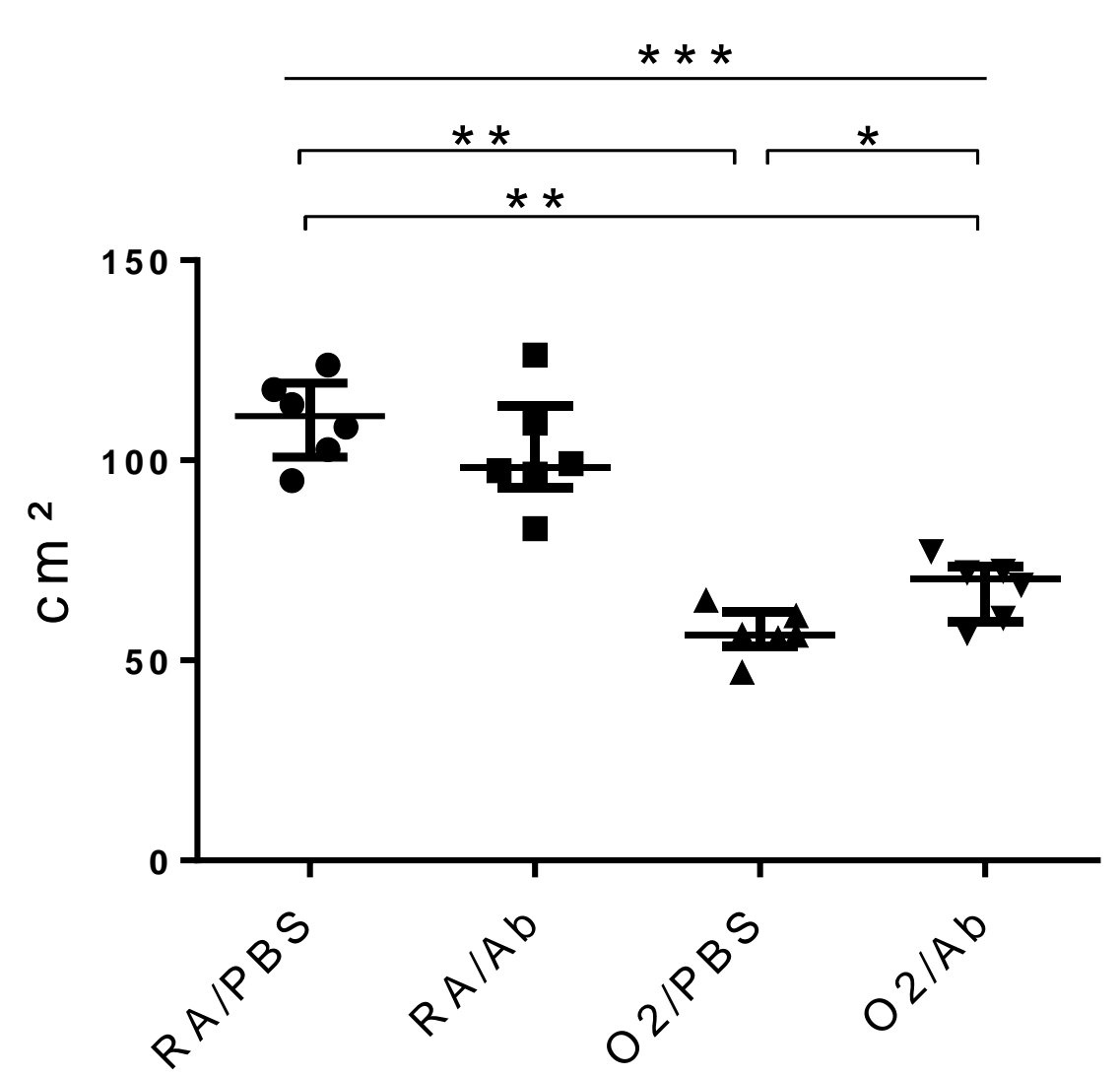

Sa

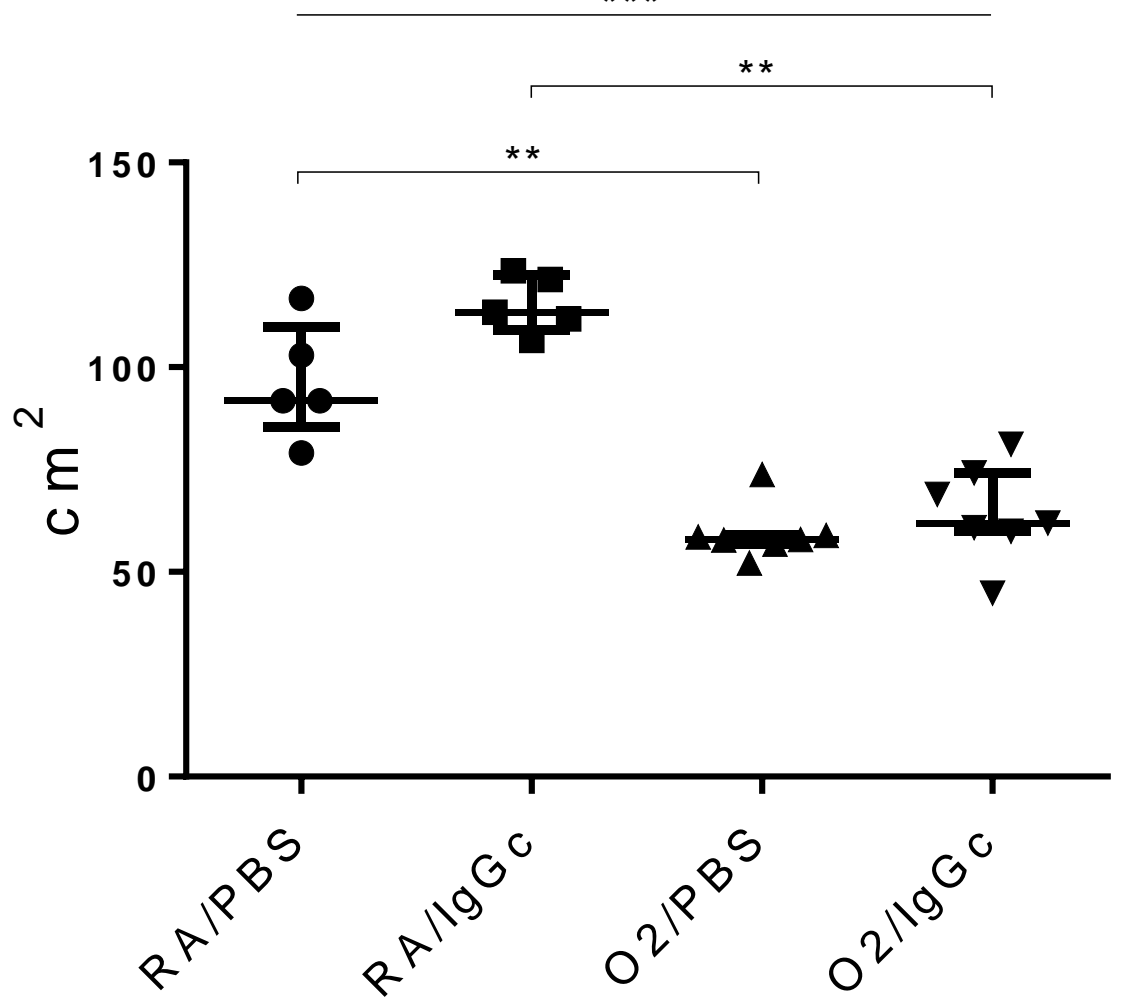




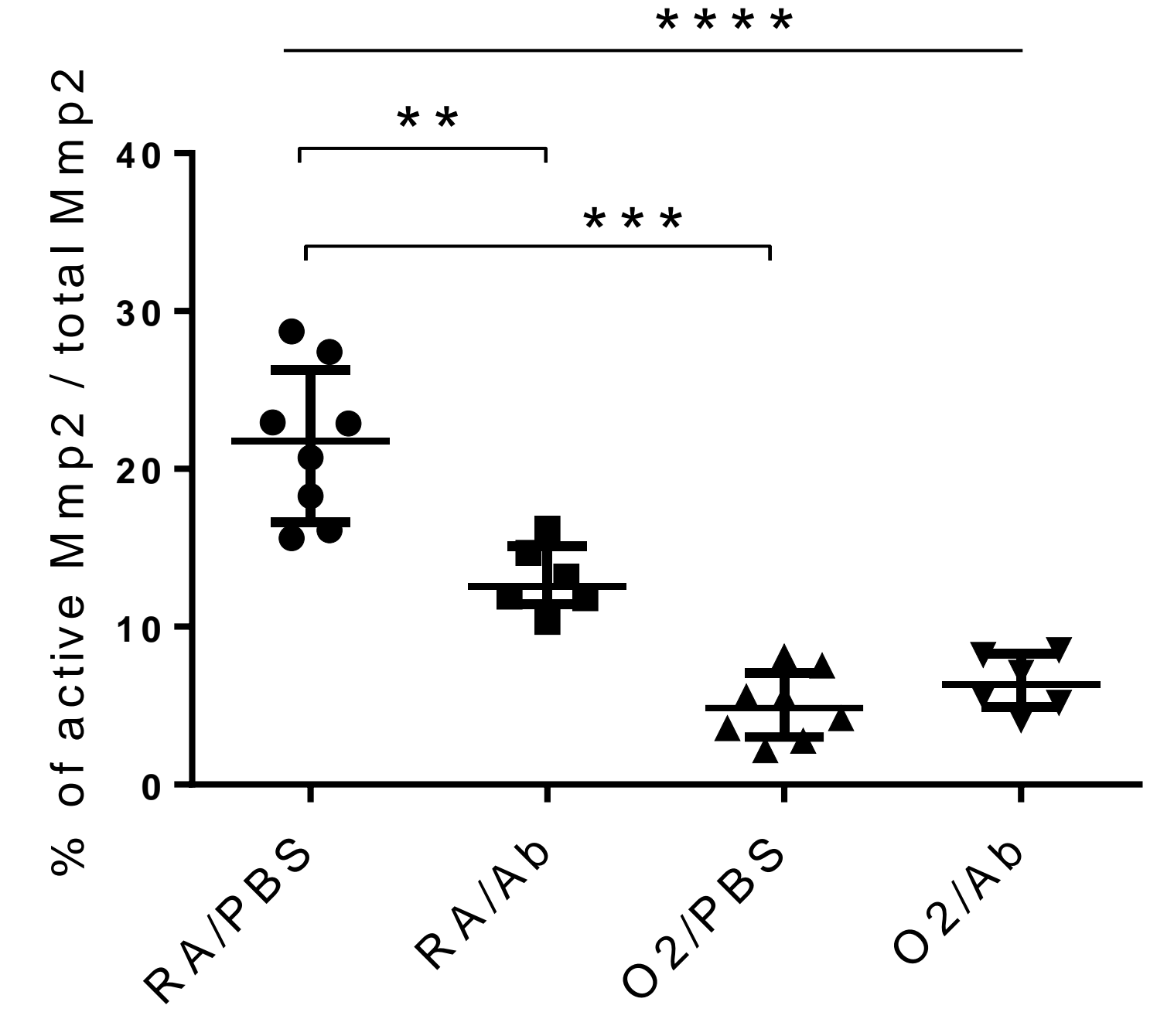


Vegfa

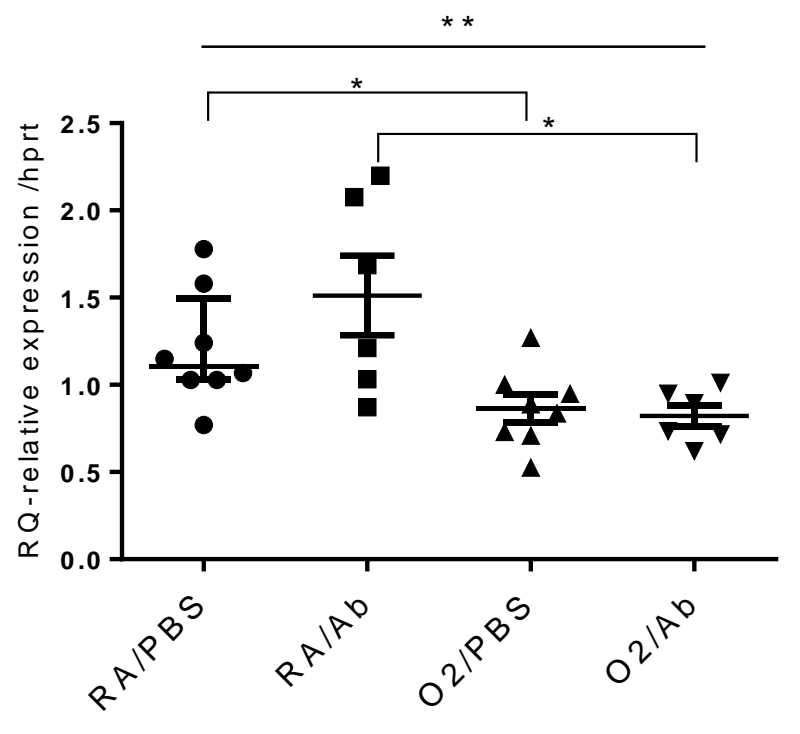

Fgf18

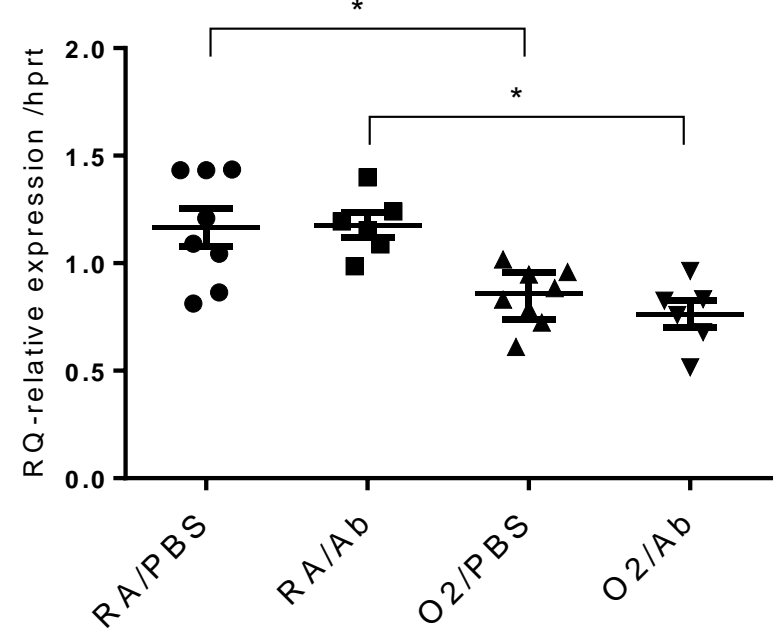

Fgfr3

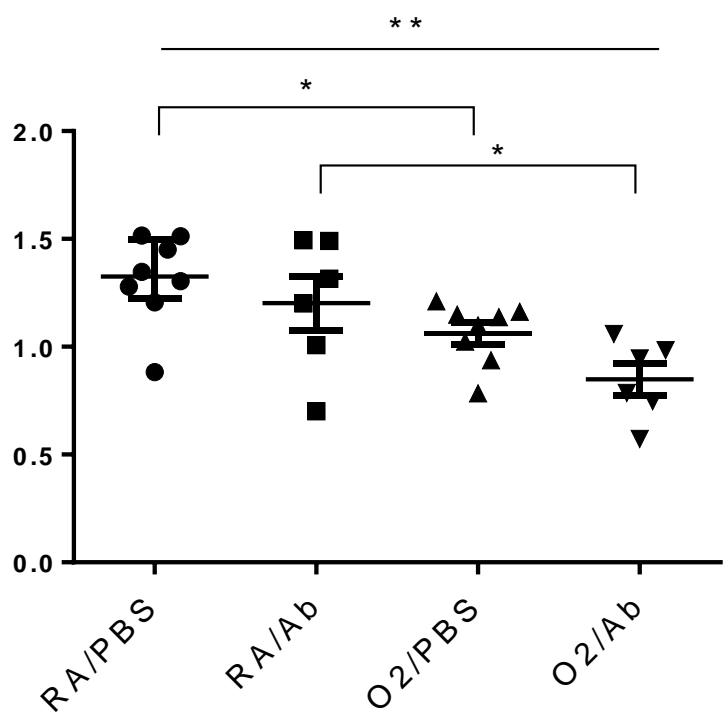

Pdgfr

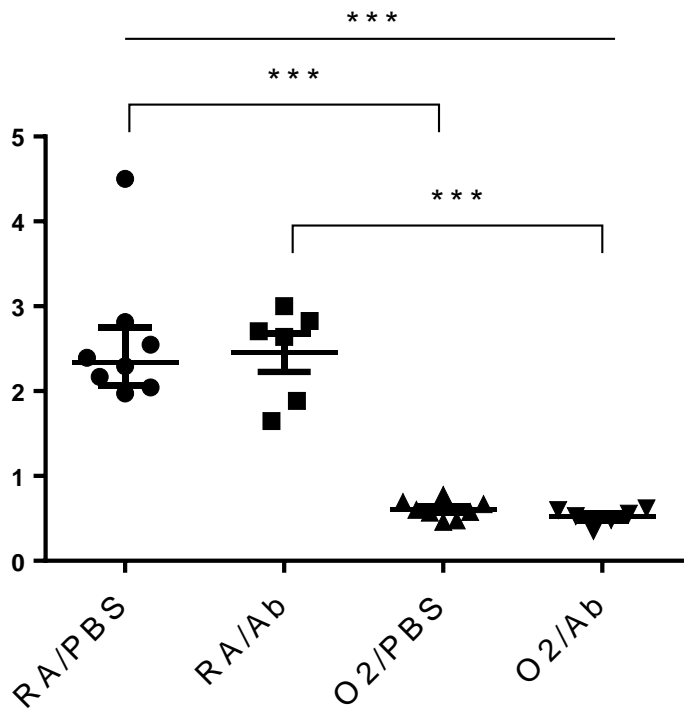

Fgfr4

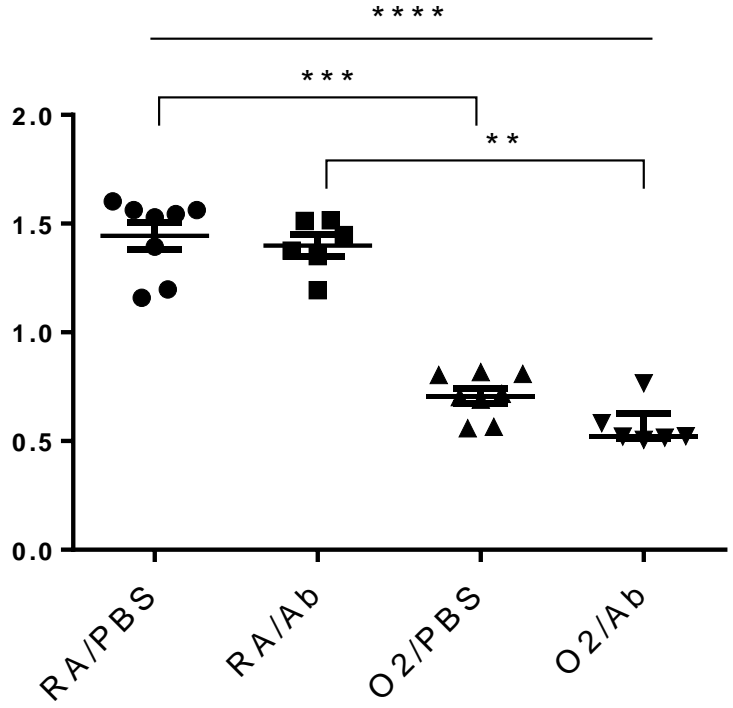

Tgfb

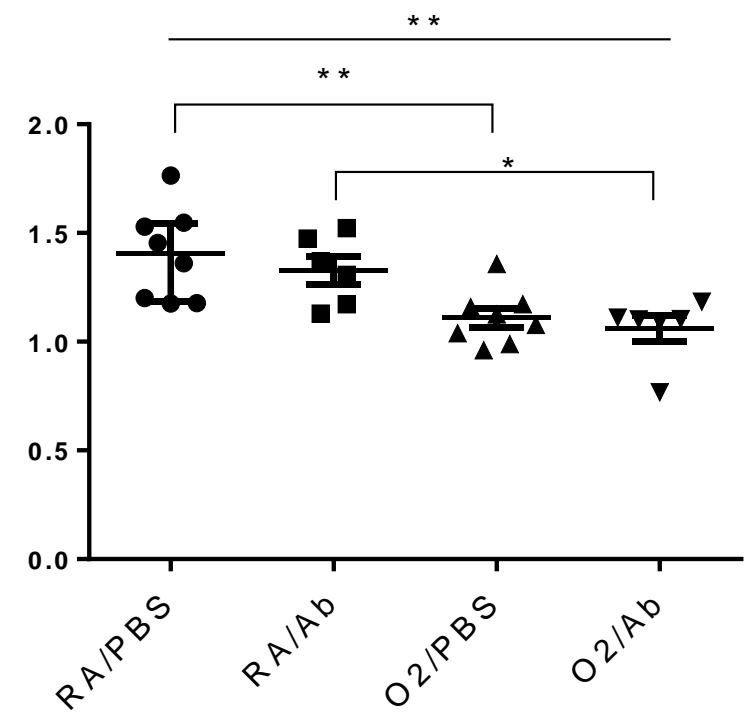



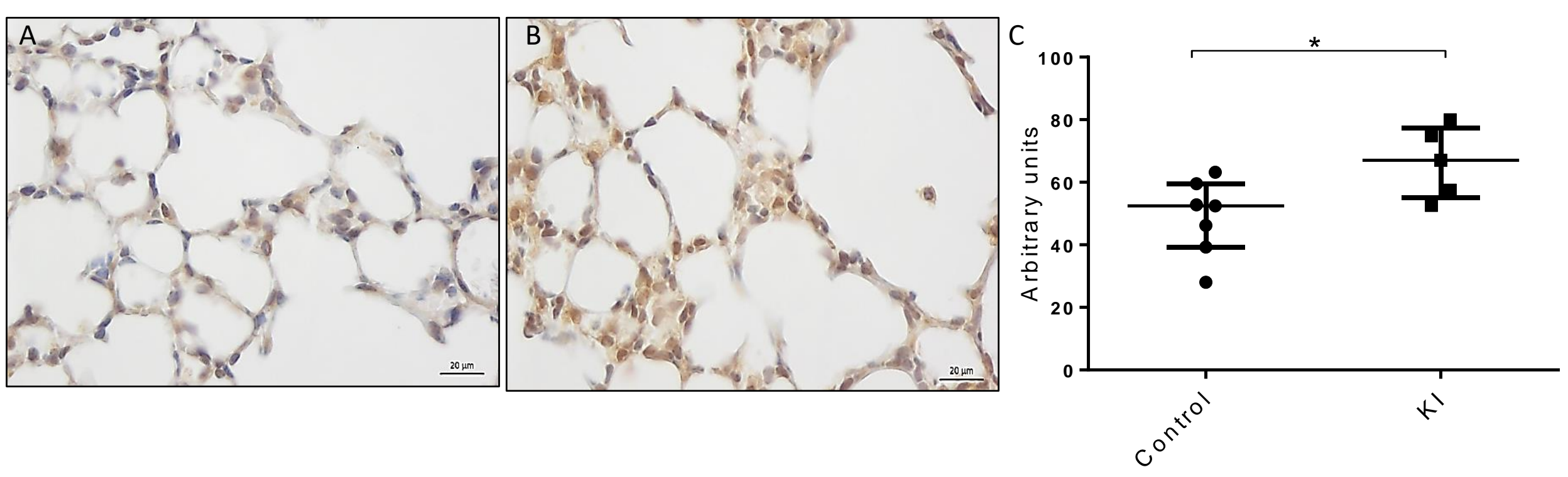
1.
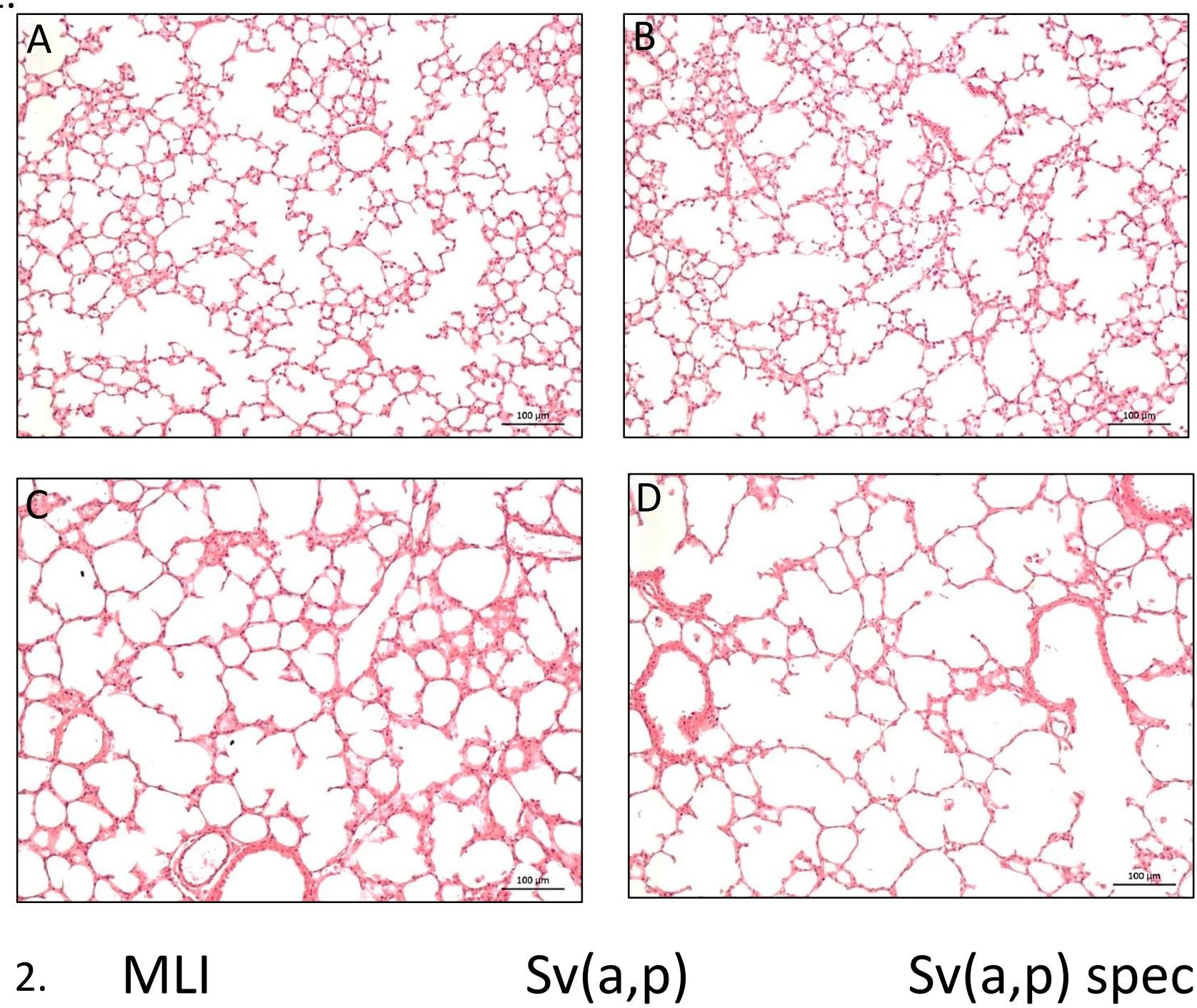

$\operatorname{Sv}(a, p)$

Sv $(a, p)$ spec

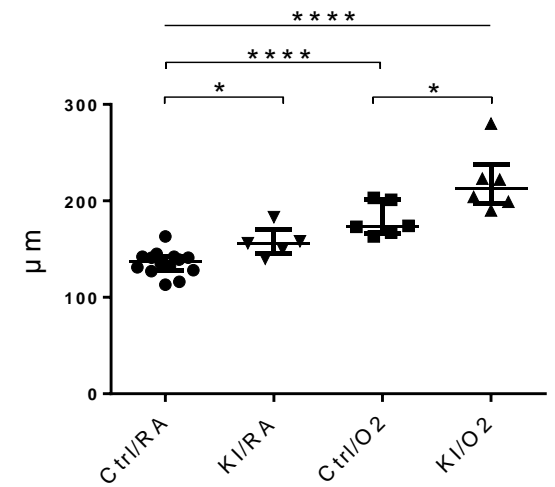

Sa

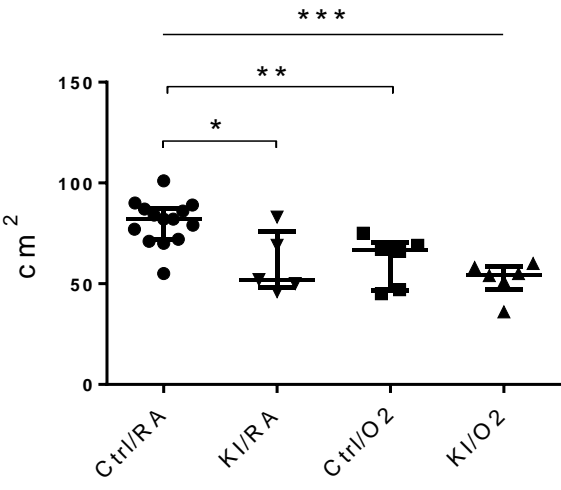

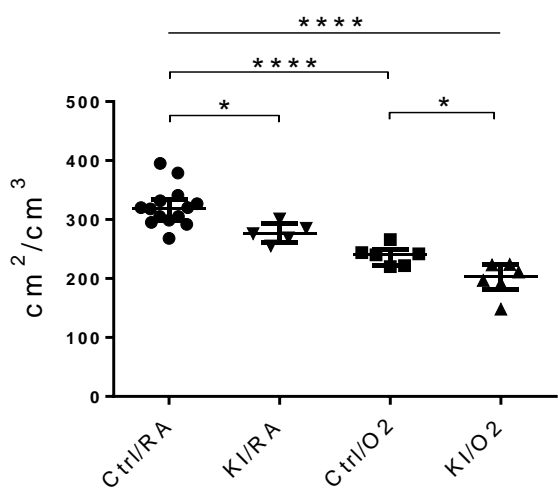

Sa spec

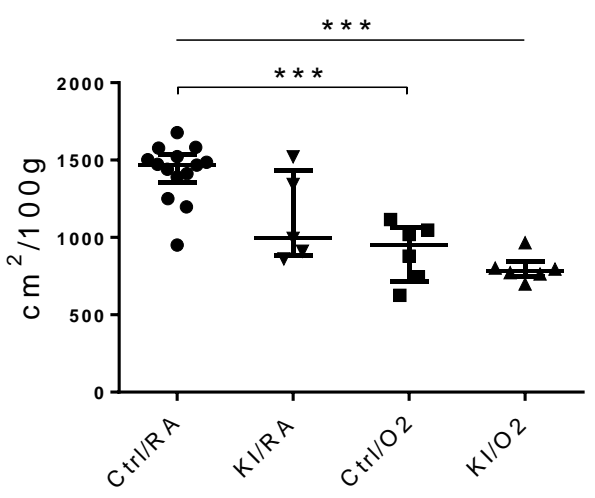

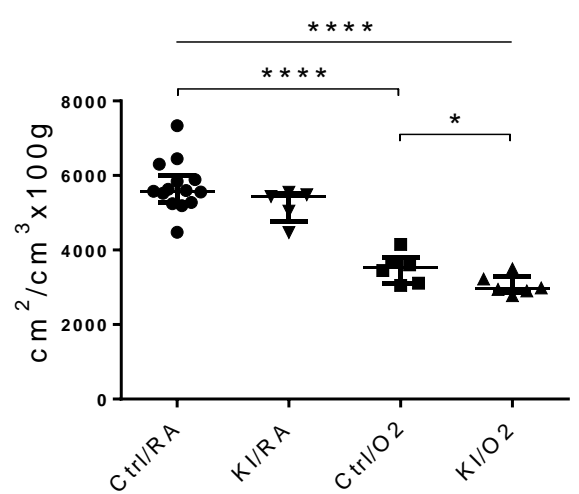

RAC

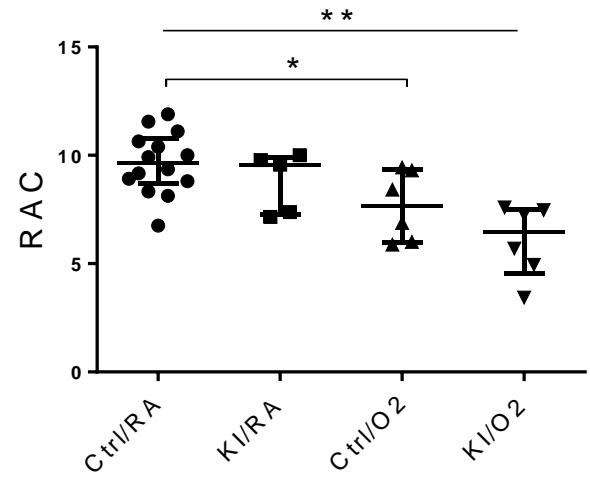




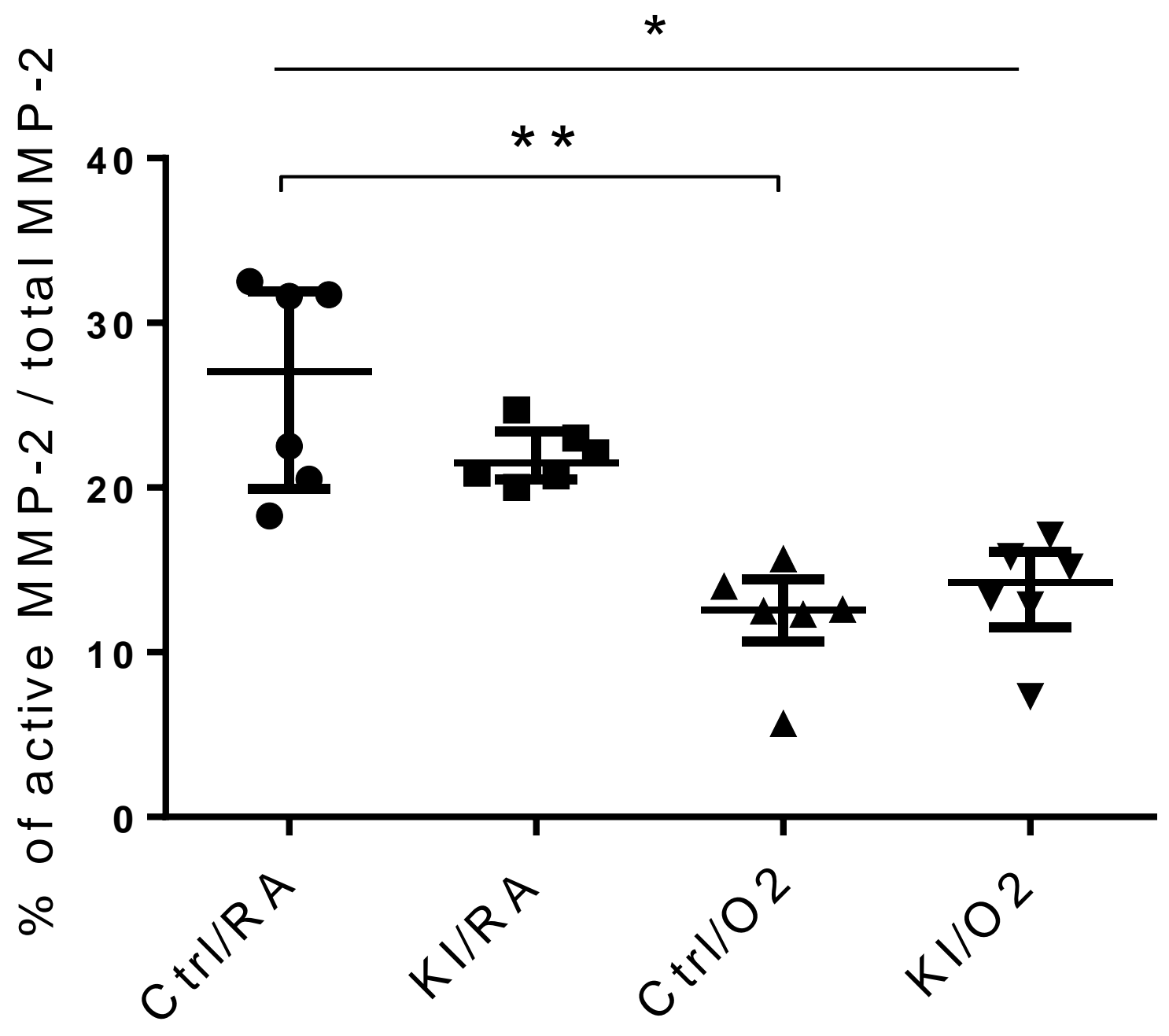




\section{Vegfa}

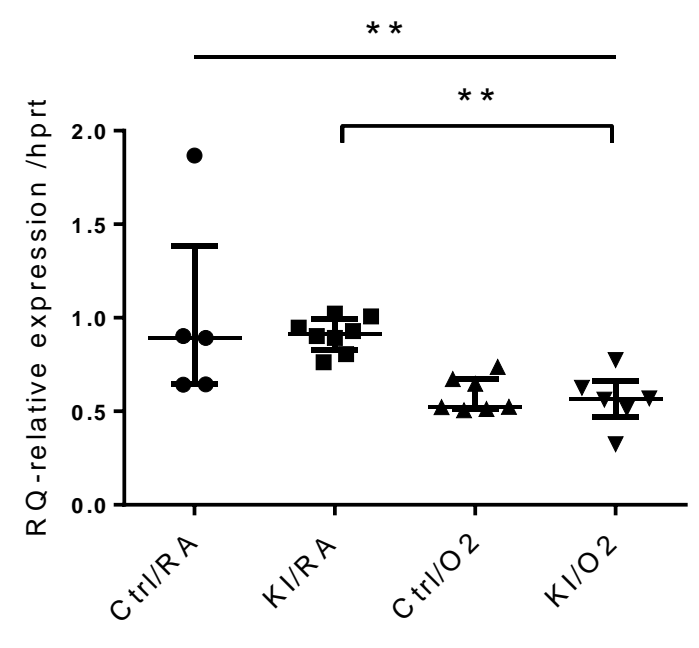

Fgf18

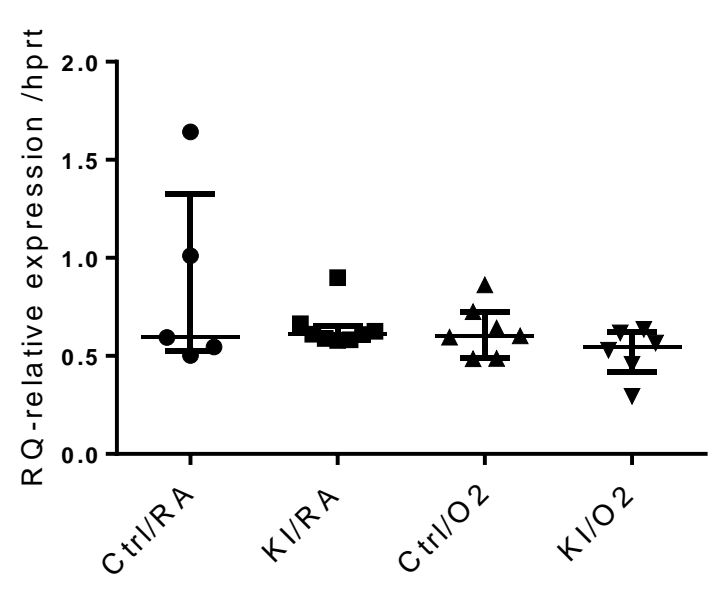

Fgfr3

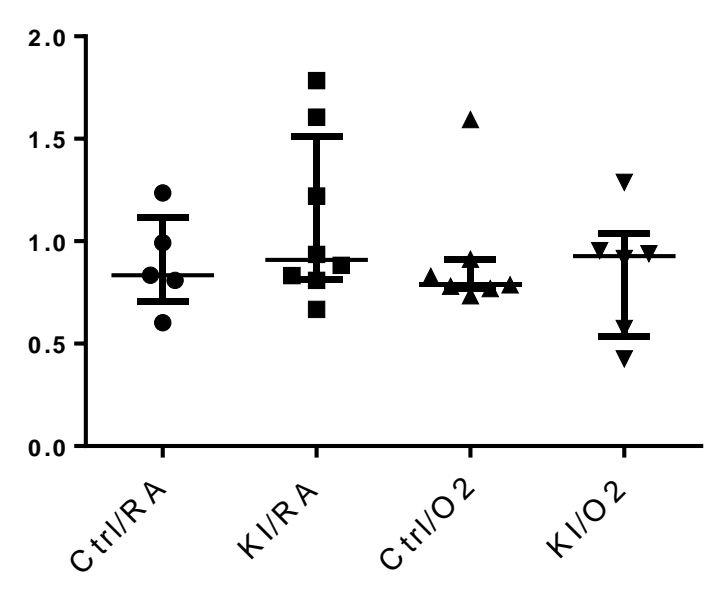

Pdgfr

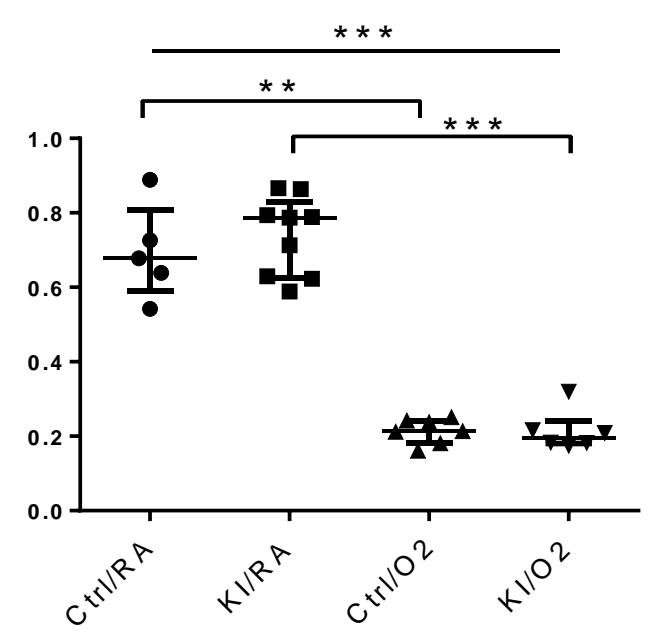

Fgfr4

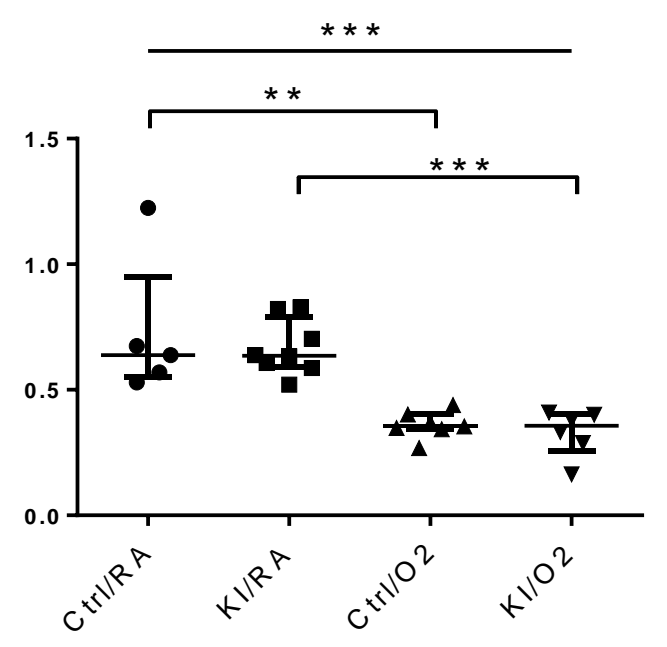

Tgfb

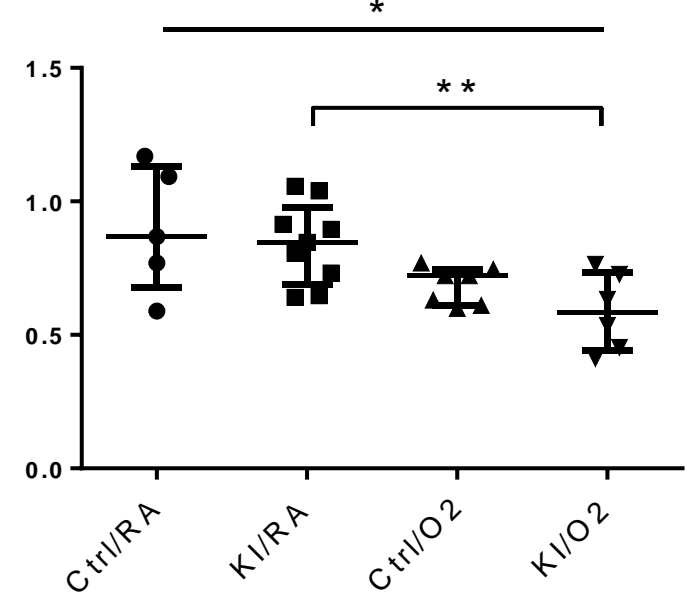

